\title{
EENIGE GEGEVENS OVER DE HINDOE-OUDHEDEN VAN OOST-JAVA
}

VOLGENS EFN HANDSCHRIFT VAN

J. HAGEMAN J. Cz.

(1861-1868).

Dat bij de betrekkelijke karigheid der gegevens, die ons voor de studie der Javaansche oudheden ten dienste staan, beschrijvingen van momumenten en beelden van zeer groot belang kunnen zijn, ook al voldoen ze nu niet juist aan hooge wetenschappelijke eischen en al liggen ze niet verder dan een halve eeuw van ons af, is een feit, dat zich gereedelijk laat verklaren door de groote veranderingen, die juist in die laatste halve eeuw de toestand van talrijke oudheden ondergaan heeft, een tijdperk, waarin de belangstelling voor en bescherming van de oude monumenten helaas geen gelijken tred heeft gehouden met de snelle uitbreiding van waterstaatswerken, spoorwegen, cultuurondernemingen en soortgelijke vernielende elementen. Zoo zijn de nauwkeurige en betrouwbare opgaven van Hoepermans, dateerend van 1864 tot 1867 , van de grootste waarde gebleken voor de vaststelling der geschiedenis van allerlei bouwwerken en andere oudheden ${ }^{1}$; en zoo was het dan ook met groote verwachtingen, dat wij kennis gingen nemen van het ongeveer gelijktijdige (1861-1868) handschrift van Hageman, deel uitmakend van diens legaat aan het Kon. Instituut voor de Taal-, Land- en Volkenk. v. Ned. Indië en bewaard in de Koloniale Bibliotheek ${ }^{2}$, een handschrift, op welks bestaan de Heer G. P. Rouffaer onze aandacht gevestigd had. Immers Hageman was de eenige, die gedurende die jaren op Oost-Java in deze richting werkzaam was en al munt ook de verdere arbeid van dezen autodidact niet door degelijkheid uit, toch krijgt men den indruk, dat de weinige waardeering, hem tot zijn teleurstelling van de zijde der leidende wetenschappelijke persoonlijkheden te Batavia betoond,

1 Uitgegeven in de Rapporten van den Oudheidkundigen Dienst over 1913.

2 No 24 van de handschriften uit Hageman's nalatenschap. 
inderdaad niet geheel billijk was. Men kon althans verwachten, dat zijn mededeelingen zeker even belangwekkend als die van den minder ontwikkelden Hoepermans zouden zijn en tevens een uiterst gewenschte aanvulling zouden geven van het werk van laatstgenoemde, welke juist het Oosten van het eiland niet bezocht heeft.

Aan die verwachting heeft het handschrift slechts zeer ten deele beantwoord.

Al dadelijk bleken er op min of meer troebele bronnen berustende overzichten van jaartallen en daaraan vastgeknoopte beschouwingen over de oude geschiedenis bij te zijn, die volstrekt waardeloos waren. Ook de stukken aangaande den godsdienst der Hindoe's en Javanen en die over de tijdrekening enz. der Tenggereezen konden, bij wat thans daaromtrent bekend is, dadelijk ter zijde worden gelegd. Doch zelfs het gedeelte, dat de eigenlijke beschrijving der oudheden bevatte, was herhaaldelijk teleurstellend. Zeer veel van de behandelde zaken heeft de schrijver klaarblijkelijk zelf niet gezien, althans hij is in heel wat gevallen tevreden met het geven van een compilatie uit de hem (en ons) bekende bronnen. En waar hij een eigen beschrijving geeft is hij ook nog dikwijls bedroevend oppervlakkig en onvolledig. Een vergelijking met Hoepermans valt dan ook allerminst in zijn voordeel uit; dat bleek vooral bij de residentie Kediri, de eenige, die door beide onderzoekers bereisd is, en waar dus beschrijvingen van zelfde bouwwerken vergeleken konden worden. Zonder uitzondering was dan die van Hoepermans verreweg de beste.

Voor publicatie als geheel kwam om deze redenen het handschrift van Hageman, dat den titel draagt: "De Hindoe-oudheden van Oostelijk Java» en verdeeld is in 451 paragraphen, niet in aanmerking. Doch geheel verwerpelijk was het daarom nog niet. Immers omtrent de oudheden der residenties Besoeki, Pasoeroehan, Soerabaja en Madoera bevat het een aantal bijzonderheden, die van elders niet bekend waren, en hoewel wij ook hier de beschrijvingen wat vollediger en nauwkeuriger gewenscht zouden hebben, blijven ze in zulke gevallen toch altijd de groote waarde van eenige bron behouden. Er bestond dus alle aanleiding tot een gedeeltelijke uitgave van het handschrift, d. w. z. van die gedeelten, welke iets nieuws inhielden.

Dat nieuws is overigens niet uitsluitend van Hageman zelf Dl. 72 . 
afkomstig, doch gedeeltelijk ontleend aan een handschrift van H. N. Sieburgh. Gelijk bekend is, vertoefde deze schilder van 1837 tot 1842 op Java, bezocht zeer veel tempels en vervaardigde daarvan een aantal schilderstukken, plattegronden, doorsneden en andere teekeningen en schetsen, thans bewaard in 's Rijks Ethnographisch Museum te Leiden. De bedoeling was, dat een en ander zou dienen voor een groot werk over de Javaansche oudheden, waarbij Dr. van der Vlis den tekst zou schrijven volgens aanteekeningen van den schilder. Van die aanteekeningen makkte laatstgenoemde een excerpt ten behoeve van resident De Vogel, en het is dit uittreksel, hetwelk Hageman geraadpleegd heeft ${ }^{1}$.

Hieronder volgen dus die gedeelten uit Hageman's handschrift, waarin iets voorkomt, dat voor de geschiedenis der Oost-Javaansche oudheden belangrijke aanwijzingen geeft. Uit den aard der zaak hebben wij den tekst ongewijzigd gelaten; alleen was het op verschillende plaatsen noodig eenige bekorting aan te brengen en bv. beschouwingen over den eeredienst, naamsafleidingen enz., die al te onzinnig waren, te schrappen. Waar het wenschelijk was, hebben wij aan het hoofd der fragmenten een korte verwijzing geplaatst naar Dr. Verbeek's Oudheden van Java (Verhand. Bat. Gen. 46, 1891) en naar de ambtelijke Oudheidkundige Rapporten en Verslagen, terwijl men ten slotte ook hier en daar in een voetnoot een enkele aanwijzing van onze hand zal vinden.

N. J. KROM.

1 Zie over Sieburgh: de Jav. Cour. van 20 April 1842, De Kopiïst van $1842 \mathrm{n}^{\circ} 3$ (p. 380-388) en het artikel van Leemans in de Algemeene Konsten Letterbode van $1846 \mathrm{n}^{\circ} 44-46$, overgenomen in de Jav. Cour. van 27 Maart $1847 \mathrm{n}^{\circ} 25$. 


\section{MATJAN POETI.}

(Verbeek n॰ 666 en 667; Rapp. 1903 p. 49; 1904 p. 143; Oudh. Versl. 1915, 2, p. 61).

Oostkust van Java, Zuid van Banjoewangi, ongeveer zes palen, - ook gezegd tien palen Zuidwest. Ongeveer twee honderd voeten boven zee, vier palen van de kust. Op een effen bodem, aan de vereeniging van twee riviertjes, Sebani en Tambong.

Omvang: drie palen - één uur - vijfkwartier uurs omgaande ; rood baksteenen muur, waarvan in $1820,1822,1844$ nog eenige gedeelten staande gebleven waren; twaalf voet hoog, zes voet dik, met gang en borstweer van binnen. 1862 reeds geheel vernield, met geweld, om elders de steenen te bezigen, voor den bouw eener residentie-woning te Soekaradja.

Binnen die ommuurde ruimte, doch meer naar de Oostzijde, staan of stonden:

1. De ruïne van een zetelvormigen tempel, van zachten kalksteen; stukken van veertien duim lang, zeven duim breed, drie en een halve duim lang [lees: dik]. Enkel de zij- en achterwanden staan nog. De boven- en voorzijde is open. Men komt langs een trap in de ledige ruimte $(1822,1860,1862)$.

De steen is van dezelfde, als in het Zuiderdeel van 't land gevonden wordt, kalkformatie geelwit. De rooden baksteen is gelijk aan die van elders: "Batoe modjopait».

Twaalf voet hoog en breed, en twintig voeten diep; binnenwerks met baksteenen wanden. Buitenwerk: vierkante vakken met ribben, lijsten, rosetten; acht vierkanten voor het hoofddeel, een voor het vooruitsteekend trapdeel, aan elke zijde. Op een voetstuk, van vier lagen rooden baksteen, boven den grond. In het midden van elk vierkant vak, aan de buitenzijde, eene uitholling, als een miniatuurnis.

Het fondament had de vorm van een reusachtigen schildpad, omwonden door twee groote serpenten, wier hoofden vooruit, en wier staarten achteruitstaken, - of, zooals Reinwardt in 1822 meende, een kaaiman en draken. Bik zegt: een draak of monster van gebakken steen (1822); Epp zegt: schildpad en slangen (1844). 
De optrede, het portaal, had de vorm van halve manen; zeer beschadigd, vernield. Rondom den tempel op eenigen afstand groepen van beeldgedrochten. Eén daarvan moet wel dertig voeten lang geweest zijn; alles van gebakken steen. Rondom nog vele gefigureerde baksteenen, die tot het beeldwerk behoord hebben. Alles bedolven onder humus en struiken; kop en staart van den draak nog zigtbaar (1822).

Voor ongeveer tweeëntwintig jaren, was de tempel, waren de krokodil en het groote gedrogt, nog in hun geheel. Door den toen kommandant Clement de Harris waren eenige losse beelden weggehaald, en naar Soerabaya verzonden (1787-1799).

Crawfurd spreekt van gedrochtelijke beelden van Banjoewangi (III, 230). In 1822 waren alle beelden van Matjanpoeti verdweenen, want de door Reinwardt bedoelde zijn gebouwen geweest, of groote beeldzuilen.

De trapingang is aan de Westzijde. De voorstelling op de plaat bij Van Hoëvell (II, 195) is van de thans begroeide Zuidzijde. Bik nam twee afteekeningen, die later bij Mieling in den Haag gereproduceerd zijn (1852).

$\mathrm{Ik}$ vond alles ongeveer als in 1822 , maar opgeruimd, vrije omgeving, onder eeuwenoude Waringin. De graauwe kalksteenwand scheen mij hard, weinig poreus. Het loof-, lijst-, rosetwerk was zuiver (1863).

2. Vóór, dus West van dezen zeteltempel, zijn de fondamenten van een gebouw, dat zeker een open halle was, verbeidplaats.

3. Regts, dus Noordwaarts, was in 1822 reeds, en vond ik veertig jaren nog, een roodbaksteenen steenhoop, met een gedeelte muur, dat gesculpteerd scheen, gebeeldhouwd, en dat het "reusachtige dier van dertig voeten» van Reinwardt zal geweest zijn; een groot, rijkbewerkt, pyramidiaal oploopend algemeen Kalahoofd, met handen, rosetten, bloemwerk (Afbeelding van Epp bij Van Hoëvell II, 196).

4. De roodbaksteenen muur, die de aloude stad Matjanpoetih omgaf, door Van de Poel opgegeven drie palen omtrek, die door Bik en door Reinwardt in $1822 \mathrm{nog}$ is gezien, deels staande, die door Van Hoëvell in 1847 nog wordt aangeduidt als door Epp, twaalf voet hoog, zes dik, met gang en borstweer. Ik vond die muur in 1862 afgebroken; zelfs het fondament uitgebroken, het volk er nog aan bezig, en met karrevrachten 
aan 't vervoeren der steenen, op order en ten behoeve van den hoofdman van bestuur.

5 . In het nu woest gedeelte en in de omgevende koffijtuinen komen steenhoopen en grondslagen voor, vroegere woningen van voornamen; van lieverlede opgeruimd als minder waard dan de koffijboonen.

Dit alles is van ooggetuigenis en tijdgenooten: Reinwardt, Reize, uitgave 1858 , blz. 618,619 ; Th. Bik, reisgenoot, T. B. G. XIV, 176; Van Hoëvell, Reis, II 195-7; Epp, T. N. I. 1849, II, 138-257, woonde er; Epp, Herinnerungen Schilderungen (1852), 482; platen van Bik, Epp, Mieling.

In de Java Government Gazette van 29 Febr. 1812 komt voor, in een brief uit Banjoewangi van 31 January 1812:

"Men verhaalt mij, dat omstreeks zes of zeven mijlen van hier, de fundamenten zijn van een zeer groote, oude stad, die gebouwd was van gebakken steenen van zes of zeven duim dik, en evenredig lang en breed.

"Ik heb verscheidene beelden gezien, die uit deze ruïnen opgedolven waren. Onder dezelve is een tamelijk wel behouden Ganesa-hoofd. En vindt men vele beelden in levensgrootte van Gopis, die eerbiedig voor Krisnja buigen. Er zijn twee of drie, waarvan ik niet verklaren kan, wat zij beteekenen.

"Ik heb een koperen ketel gezien, die op dezelfde plaats was opgedolven. Hij was dun uitgehamerd, en kon ongeveer twee quarts bevatten. Geleek echter niet op eenig gereedschap van dien aard bij de Hindoe's; was uit ouderdom totaal versleten, gebroken.

"Vele inwoners van Banjoewangi kennen de namen der godheden en bezitten ook een verhaal van den strijd der goden.»

De schrijver van dezen brief is niet genoemd. In 1811-12 waren hier Residents: Neight en capt. Clarke (Ind. Magazijn 1844, IV, 243).

\section{TJANDI BANG:}

Zuidoostelijken voet van den voorberg Baloeran, aan zee. Noord van Banjoewangi, Noordoostzijde van het land Blambangan, acht palen Oost van de dessa Badjolmatti, in onbewoonde wildernis. 
Een roodbaksteenen hoop, en een soort van gedempte put, begroeid, vormloos, op het kustoeverland, en een paar grafsteden (1862) ${ }^{1}$.

De omstandigheid, dat de Portugeezen sinds 1520 ongeveer het voorgebergte noemden: Sierra do Pagoda, en eene beschrijving in 1580 nog gewag maakt van een Tempel in deze streek, doet vermoeden, dat toen nog iets meer dan de bouwval van Tjandi Bang zal hebben bestaan.

\section{POERWANEGARA.}

Op het schiereiland, de uiterste Zuidoosthoek van Blambangan en van geheel het eiland Java eene ruine in de onbewoonde wildernis; vorm en juiste gelegenheid onbekend, zelfs de oude lands- en plaatsnaam vergeten en verbasterd in Proa. Op de kaart, bv. van Van de Velde, is Proa een dorpje, en ook de naam van geheel het schiereiland.

Dit is het vroegere Poerwanegara. Wat er van rest is onzeker; de landzaat waagt er zich niet heen. Men duidt aan: muren en grondslagen. Op de tegenover, om de Oost, liggende uithoek van Bali, zoogenaamd Cabo di Porco, varkenshoek, staat een tempel aan de zeegod gewijd. Dit zal ook met Poerwanegara het geval zijn geweest.

De tempel op het tafelpunt, Boekit Badong tegenover Blambangan, heet Oeloewatoe, is gewijd aan Sang Manik koemawang, het schitterend edelgesteente, is de parau van Dewi Danoe en ligt op een uitstekende rots aan zee.

\section{KERADENNAN.}

Om de Zuid van Blambangan. Aan de voorname rivier Setahil, die van Noordwest naar Zuidoost en Oost afvloeid. Nabij de plek, aan baai Pampang of Plambang, waar eenmaal de hoofdplaats stond van het land Blambangan.

In de tegenwoordige dessa Keradennan worden grondslagen van roodbaksteenen gebouwen van ouden tijd gevonden, evenals in West-Blambangan, gezegd: Poeger, Bondowosso.

De verbastering is: Kradinan. Dit was de hof-verblijfplaats, nu sinds eene eeuw verwoest ${ }^{2}$.

1 Vgl. ook Rapp. 1904 p. 142, aangaande een Zuidelijker gelegen overblijfsel.

2 Vgl. Rapp. 1904 p. 146; Verbeek n 669. 


\section{DJANGKAR.}

Te Ardjasa zijnde, 1862 Augustus, werden daar aangebragt, als gevonden te Djangkar, ongeveer ter plaatse waar Sandapoera moet hebben gestaan, twee vierkante holle voetstukken, van een paar voet hoog en breed, met lijstwerk, dierkoppen, loofwerk, van gebakken lava-asch, grijs graauw als trachiet, deels geschonden, gevonden in den grond bij het graven van een waterleiding. Als antiquiteit hadden deze twee "aarden potten * minder hooge waarde, dan wel de zeldzaamheid, en de versierselen, die Hindoesch waren (Not. B. G. II, 307; III, 1).

De voetstukken schijnen voor Hindoebeelden gediend te hebben, en waren eenigsinds naar Chineesche wijze van "zitpotten.. Ik nam er eene teekening van, en zond die naar het Bataviaasch Genootschap, - zonder gevolg (Not. B. G. II, 307).

Ik toog nu zelve naar die streek om naar verdere overblijfselen der oudheid te zoeken, eerst te Assembagoes, toen te Djangkar. desa aan zee, van waar men mij eerst per vaartuig bragt naar de kustwildernis van Tandjong Djangkar, waar ik een ingesloten plekje vond met twee graven van nieuwen datum. Vandaar bragt men mij weder naar Djangkar, vervolgens landwaarts Westelijk op, door de dessa Gadieng, tot weder bij de kust. Daar toonde men mij, in eene bebouwde streek onder geboomte wringin, die niet zeer oud scheen - een regt opstaanden steen, van ongeveer anderhalf voeten hoog, een half voet dik, hartvormig, rond gewelfd naar boven, doch bovenop een eigene ronde verhevenheid. De steen was van graniet zoo het scheen, dus niet van inheemsche trachiet.

Zonder eenig teeken of opschrift. Zonder eenig ander bewijs in de nabijheid, - een oogenschijnlijk bedolven veld, nu eerst kort geleden omwoeld, bewerkt ${ }^{1}$.

\section{LAND VAN POEGER.}

Op deze uitgestrektheid lands worden vele overblijfselen van vroegere eeredienst en heerschappijen gevonden. De ouderdom is evenwel niet hoog opgaande: het Hindoeïsme, de leer der

1 In deze streek zijn later de beschreven steenen van Agel en Widarapasar bekend geworden (Verbeek $\mathrm{n}^{\circ} 663$ en 664; Rapp. 1904 p. 150). 
goden, is geene eeuw geleden verdreven. De historische lokale bijzonderheden duidden aan:

1. Noordwesterdeel. Kadaton Toengal Koeripan, Andong Biro (zie de beschrijving) ${ }^{1}$.

2. Noordwesterdeel evenzoo. Argopoero-top(elders aangeduid). ${ }^{2}$

3. Zuidwesterdeel. Koetoboro (zie elders).

4. Westen. In de wildernis, in nu moerassig land, benoorden Kentjong-Koetoboro, worden grondslagen gevonden van eene zetelplaats, genaamd Kedawong, Kadawoeng, rooden baksteen. $^{3}$

5. Westerdeel. Grondslagen van eene stad, die genaamd was Poerwonggo, en omstreeks het tegenwoordig Tangoel lag.

6. Oosterdeel om de Zuid. Blatter, rood baksteenen muren in de thans moerassige wildernis beoosten Poeger. Blatter ligt nu Oost van Sabrang, dat acht palen Oost van de tegenwoordige negorij Poeger. Van hier, bij Sabrang, begint nu onbewoonde wildernis tot aan het gebergte, waar weleer bevolkte oorden waren. ${ }^{4}$

7. Oosterdeel. Makětěp bij Kademangan en Kaseleer; rood baksteenen grondslagen. De muren staan deels, zijn deels bedolven, tot zes voeten diep in den grond begraven.

8. Noordoosterdeel. Kepattian. Vierkanten, muren van gebakken steen in de nu verlaten wildernis begraven.

9. Noordoostop. Krandjingan, vier palen beoosten Djember. Eenige steenen beelden van Siva-kultus, verminkt. ${ }^{5}$

10. Noordop, van Poeger. Kemiri, aan de Zuider helling van het Yanggębergte. Een antieke pot, vermoedelijk het overgebleven deel van een Yoni-standaard, gezegd altaar voor een Lingga.

11. Oosterdeel. Kotta Prangalas, bij de kotta Maketep $\left(n^{\circ} 7\right)$, evenzoo in wildernis; het bewijs dat hier eenmaal eene versterking stond, van rooden baksteen gebouwd.

12. Noorderdeel. Grondslagen van muren, vier en een halve paal verre, in de thans dessa's Tal ${ }^{6}$, Tapen, Soempilan, distrikt Wonosari. Hier stond weleer het woud Wono-kiroen, tegen de Noordwesterhellingen van het Raung-gebergte.

1 Deze beschrijving van de bekende Tjandi Kĕdaton is niet overgenomen.

3 Evenmin opgenomen.

3 Verbeek n० 649; Rapp. 1904 p. 139.

4 Verbeek n० 651; Rapp. 1904 p. 141.

V Verbeek n ${ }^{\circ}$ 653; Rapp. 1904 p. 135.

6 Vgl. Rapp. 1904 p. 148; Verbeek n 659. 
SMEROE.

(Verbeek no 613; Rapp. 1902 p. 345).

In 1841 vond H. N. Sieburgh in den tuin van den heer Hofland te Passaroewan een "uitsteekend schoon beeld, dat van den berg Smeroe was gehaald van eene plaats waar overigens geen spoor van eenen tempel gevonden werd.»

$\mathrm{Er}$ is mij vroeger geen andere plaats van gevonden oudheden voorgekomen, als om de West, in het bosch Soengi-petoeng, aan den voet van het algemeen Smeroe-gebergte, - om de Oost, de Tjandi Ngardipoero $=$ Ardipoeri, ook aan den algemeenen voet van die zijde.

Tijdens een bezoek van drie bergbestijgers op 22 July 1867 , werd het eerst vernomen, en in Juny 1868 door een anderen bergbezoeker bevestigd: dat voor eenige jaren geleden de Javaan $\mathrm{Pa}$ Rasido uit de bergdessa Ngadas, tijdens een zwerftogt naar en om den Smeroe, op zekere plaats aan de woudgrens, Noordzijde van den algemeenen bergkegel Mahameroe "een vrouwelijk beeld vond, naar 't Noorden gekeerd». Hij noemde dit beeld: Giri Simeroe, en de plaats zelve, eene kleine opene ruimte in het woud: Poetjoek Batoor Koetoegan.

Dáár werd ook vaatwerk gevonden, waarin water was, dus potten, heele en gebrokene, in den omtrek, op deze hoogte van 10 à 11.000 voet.

In 1868 werden gevonden zeven waterputten en vele potscherven, ook het vrouwelijk beeld, dat een Parvati schijnt te wezen, en dat men noemde Giri Smeroe of Retjo tjoengkoep.

Nadere opgaven van Raden Endrokesoemo, patih te Loemadjang, bij navraag over het gevonden beeld en de putten, duiden het gevondene beeld niet voor een vrouwelijk, een Parvati, maar voor een Mahadewa, of een Siva als boeteling. De opgave is als volgt:

«De Retjo Tjoengkoep, hoogte anderhalf voet. Een buikband om den middel. Mannelijk beeld, staande op den blooten grond. Twee handen; de linker ledig; de regter vat een toembak tjengkreng [tjrengkeng] (trisoela). Tiara (djamang) op het hoofd als een bruid. Opperarmen met armversiersels, beide. Gadja oeling in de ooren, evenals de tegenwoordige bruiden in tooi.»

Een bezoeker jager naar den Smeroe, die er op 21 November 1867 en op 12 April 1868 heenging, W. J. H. Hulskamp, 
duidt aan bij nota 18 April: "van een hutje aan den Goenong Kepolo de Noordzijde van den. Smeroe op, tot Koetoekan, waar de gids $\mathrm{Pa}$ Rasido wachtte. Hier is een beeldje, waaraan werd geofferd door den gids."

Over de zeven putten wordt door den reiziger Endrokesoemo aangeduidt: "stil bezonken water, niet opwellend. Rondom gemetseld met witten steen (batoepoeti).»

\section{TJANDI NGARDIPOERO.}

(Verbeek n 631; Rapp. 1904 p. 122).

Wanneer deze oudheid het eerst is bekend geworden aan de wetenschap, blijkt niet.

In 1844 vernam Junghuhn van den toen Assistent-Resident van Probolinggo - J. D. van Herwerden of H. D. Potter (1840-1848) - wat hij op blz. 379, deel II T: N. I. VI (1844) mededeelde :

"Djandi Artipoeri, rooden baksteen, bij het dorp Doekoepenangal. Z. O. helling van den Smeroe, veertien(?) Engelsche mijlen van Loemadjang, in een streek waar zich tot aan het Zuiderstrand ondoordringbare bosschen uitstrekken. Hoogte boven zee eenige honderd voeten.»

Rigg, 1846, Singap. Tijds. $563=$ Artapuri.

Mij is geene aanduiding over deze Tjandi voorgekomen in de bijdragen van reizigers, IJsseldijk, Brouwer, Rengers, Herwerden. De afgelegenheid is te verre.

Toen ik in Augustus 1861 te Tempêh was, stelde ik eenige Europeesche ondernemers tabaksplanters voor, de ruïne te gaan opsporen, en ik vond spoedig bijval.

Niemand had immer iets van het aanweezen gehoord.

Van Pasirian uit, loopen paden door ongebaande, woeste wildernissen, slingerend, zoodat de koers wel Noordwestelijk, maar onzeker te stellen is. De plaatsen die men passeert, zijn: Djarit, Selokḅesoeki', Penangal, en eene dessa die Tjandi werd genaamd. Daar is de uiterste grens der bewoonde streek, en beginnen bijna ondoordringbare bosschen, aan den onmiddelijken voet van den Smeroe, die hier, onder een scherpen hoek, zeer nabij te zien, en de krater goed op te merken is.

Een inlander van de naastbijgelegene dessa was wegwijzer, maar onzeker van de koers. Het pad moest voor den voet 
worden uitgekapt. Een woud, dat eeuwen oud scheen, liet geen uitzicht, noch zonnestralen door.

Eindelijk deed zich te midden van 't vale groen, de vuurroode reus op, de roodbaksteenen tempel, waarvan ik de bijzonderheden dadelijk beschreef, en die nader naar Batavia verzond, met de fraaije juiste teekening, gemaakt door den heer W. de Munnick.

De vorm was: vierkant, breed voetstuk, hoog ongeveer vier voet, waarheen twee trapstukken leidden. Alles rondom digt begroeid in alle poriën en reten.

Een vierkant muurwerk en binnenkamer. Vierkante deur, vierkante nissen; diep, tot onder, achter uit, een doorloopend gat, binnenwerks. Kroon en lijstwerk nog op te merken; puinhoopen van een paar altaren op het voetstuk, als nevengebouwen. Beeldhouwwerk kwam niet voor, evenals bij Tjandi Pari, delta Soerabaya.

Het omgevend bosch te digt begroeid voor nader onderzoek; overal steenhoopen en brokken.

't Bovengedeelte, pyramidiaal opgaande etage, op 't vallen, door wortelen uiteengewerkt, waardoor een onderzoek binnenwerks gevaarlijk scheen, en de vorm ontwricht was.

Hier en daar steenen soekoe, voetstukken voor beelden, op het breede tempelvoetstuk, dat met de achterzijde van het tempeltje eindigde.

De hoogte nog ongeveer dertig voeten; vierkant terras, grondstuk, ongeveer vijftien passen lang, voren, - tien à twaalf diep. Het vierkant tempeltje ongeveer twaalf voet hoog, vijftien voeten breed en lang, buitenwerks. De derde pyramidiaal opgaande hangende steenhoop, ongeveer tien voeten (1846, opgave 36 v. hoog, 13 v. breed en lang; T. N. I. 1849, II, 124).

In de nabijheid is het bosch rondom vlak land; het verschiet is gering om de digtheid van 't woud.

Ik zond de beschrijving en de teekening naar de Directie Batav. Gen. July 1862, - Tijds. B. G. XII, 510; Not. 22 Nov. 1862. Die Directie gaf ze aan den rondreizenden gekommitteerde Brumund (Not. I, 16, 46).

In January 1866 had die Directie dit een en ander totaal vergeten (Not. IV, 7-8) en zeide, niets genoegs van die 
tempelruïne af te weten. In Augustus 1866 deed ik die opmerking, nu was mijne opgave te zoek (Not. IV, 213). In 1868 verder nog niets bekend.

In zijne reisaanteekeningen van 1846, T. N. I. 1849, II, blz. 124, duidt Bleeker enkel aan: "Overblijfselen van roodbakken steen. Een tempel in Loemadjang, van 36 v. hoogte, 13 v. lengte en breedte, 30 paal van Probolinggo.» Dit was ingewonnen berigt, niet eigen opname.

Het geheel van roodbakken Modjopaitsteen. De voetstukken voor beelden, soekoe, van trachiet. Men gaf op, volgens herinnering van een oud man, dat de beelden ontvoerd, naar Banger $=$ Probolinggo ontvoerd zijn. $\mathrm{Zij}$ zullen dus in den residentstuin aldaar voorkomen.

Bij Moender, Zuid van Loemadjang, waren mede een paar beelden van de Sivakultus, vermoedelijk van hier, Ardipoero, weggehaald.

\section{KOETO-RONO.}

(Verbeek n॰ 633; Rapp. 1904 p. 119).

Middendeel van het Landschap Loemadjang. In de vlakte, bij de dessa Bondojoedo, vijf palen Noord van de hoofdnegorij, twee palen Noord van Dawoean, waar een partikulier suikeretablissement in 1861 is gebouwd; bewesten den grooten weg. Bewesten de rivier Plossotroes-Bondojoedo, in dessa, en in wildernis van glaga.

Een aantal steenhoopen zonder vorm en digt begroeid, roodbakken steenstukken van muurwerk nog opstaande. Overal verspreid liggende steenen, en brokken, over eene uitgestrektheid van wel twee palen; nu digt met glaga, hoog geboomte, begroeid, doorsneden met riviergeulen, drasgronden, en tot aan en in de dessa's Bondojoedo en Koetorono. Het is moeijelijk door die digt begroeide wildernis te dringen; te paard bijna niet mogelijk (1861 Augustus, West van Bondojoedo).

Overal bewijzen van grondslagen, afgebroken gebouwen, de steenen gebezigd voor andere doeleinden. Hier en daar in die allang-allang-glaga-wildernis een open plekje, vermoedelijke plaats van een vroeger gebouw.

Beelden van trachiet vond ik niet; beeld-, lijstwerk, fragmenten van gebakken steen, wel.

Men wees mij een steenhoop, grafstede in een digt bosch, 
onder zwaar geboomte. Dit zoude de grafstede zijn van Petjah Tondo, de Adipatti van Teroeng, de vroegere Raden Koesèn van Palembang, de latere legeraanvoerder tegen de Mohammedanen ter verdediging van Modjopait in A. J. 1400.

Deze uitgestrektheid van steenhoopen, muurgrondslagen en walstukken zoude de plaats zijn, waar eenmaal de Koeto-rono stond.

De weg naar Koetorono is, van de hoofdplaats Loemadjang uit: eerst Noord twee à drie palen, dan West over hobbelig, ruw terrein, een halve paal tot Dawoean-Soekodono, dan Noord op, kronkelend, bijna onzichtbaar, rijzend, dalend, des gevorderd bukkend, afweerend met armen, beenen en een fragment van een tak dat tot zweep dient, door struikgewas, rivierbeddingen, deels door bebouwd land, en zoo komt men in de dessa Koetorono. Die dessa ligt aan de zamenvloeijing der bergriviertjes: Pandansari, Semoet, Padang, Plossotroes en Balikambang, die alle afstroomen van de Tenggerberghellingen en Oostwaarts in de rivier van Bondojoedo vloeijen.

In die dessa Koetorono is een anderen gids noodig voor het meer Westwaarts liggend woest land, waar glaga en brokken van muren, maar geen menschelijk wezen zich voordoet. Onder den grond liggen de resten, die later eene groote stad zullen aanduiden. De uitgebreidheid der grondslagen is onbekend. Nimmer bevorens ons bezoek, Augustus 1861, kwam die plaats onder meerdere aandacht.

Ik vond geen enkele muur van eenige manshoogte, veel minder één enkel staande gebleven gebouw. Alles was vernield, door menschenhanden of door natuurlijke oorzaken.

\section{PROBOLINGGO.}

(Rapp. 1904 p. 93; Verbeek $n^{\circ}$ 634).

In den tuin van het Residentshuis staan een aantal beelden, Doerga, Parvati, Siva, Boeddha, Phallus-Lingga, Yoni, Kala.

Dit is het overschot van den roof, die de ruinen heeft ontbloot van eigendommelijke kennelijkheid voor eeredienst en toewijding: Tjandi Ngardipoero ( $\mathrm{Tj}$. Poeri) in 't Zuidwesten; Koetorono, Koetoboro in 't Zuiden en Zuidoosten; Kadaton, Kroetjil, Telogoargo, Telogosari aan de Westerhellingen van 't Yanggebergte, - alle plaatsen werden beroofd, om dien tuin te versieren; ook Batoor, Goendil. 
En het schoonste werd dan weder verder vervoerd, naar Batavia en elders.

Op de poortmuur van de groote laan, die van den grooten weg Noordwaarts strekt, staan dikbekalkte, nu onherkenbare beelden, van Sivaitischen vorm.

Onder de schoone beelden in den Residentstuin is een vier voet hooge, vierhandige, onbeschadigde Parvati, van Kroetjil hierheen gebragt in omstreeks 1858. Zie op Kroetjil.

\section{LAND VAN PADJARAKKAN.}

Verspreid liggende beelden.

Rigg duidde in 1846 aan, dat in de velden van Paiton beelden gevonden waren, langwerpige, die hij voor Lingga's aanduidde.

Te Paiton bij de Suikerfabriek vond ik eenige kleinere staande en zittende Sivaitische en Boeddhaische figuren. ${ }^{1}$

Bij de suikerfabriek Padjarakkan staan twee groote Kalahoofden, frontstukken van een tempel van bijzondere grootte. ${ }^{2}$

Bij de contrôleurswoning te Kraksan, een dergelijk Kala-hoofd; een zwaarwigtig massief stuk, gelijk aan die te Padjarakkan en te Kedawong-Passaroewan. Herkomst niet meer bekend. ${ }^{3}$

Bij de tabaksloots te Wangkal, Zuid van Kraksan, vond ik twee kleine Siva's.

In het veld op eene steenachtige plek onder de dessa Wangkal Tengga vond ik 1862: op den rand van een eenvoudigen, in den grond diep liggenden steen, trachiet, eene inscriptie van twee regels vierkante karakters van den vorm als die te Singosari 10 en 12 (T. B. G. XI, 398).

Daar nabij op een omheind plekje gronds:

Een zittende wachter met opgeheven knods, drie voet hoog, een en tweederde voet breed, anderhalf voet dik, zeer verweerd, geschonden.

Een ruwe Ganesa, drie voet hoog, mede zeer geschonden door weêr en tijd, slingerende snuit, ingedrongen beeld. ${ }^{4}$

Te Batoor, Zuiderdeel distr. Paiton tegen den voet van 't steile Hjanggebergte, stonden in 1861 nog een paar beelden

1 Rapp. 1904 p. 106.

2 Thans te Kraksaän; Rapp. 1904 p. 104.

3 Verbeek no 636; Rapp. 1904 p. 103.

4 Verbeek n 637; Rapp. 1904 p. 111. 
van Sivaïsche eeredienst, ook een Ganesa. Deze waren in 1862 naar elders ontvoerd geworden.

Op het tafelbergje Goendil, Oost van Sentool, Zuid van Bagoe, Zuiderdeel distrikt Paiton, stond een Retjogoeroe, vermoedelijk een zittend Boedha- of Siva-beeldje, dat nu van daar mede ontvoerd is geworden.

Zuid van Passangrahan Wangkal, in een Djatibosch, nabij den steilen bergwand, een steenheuvel, vierkant terras van rolsteenen ommuurd, met soort van grafstede, zonder versiering. Soortgelijke monumenten op Tlogosari en Tlogoargo. De plaats wordt genaamd Somergo: offerstede.

\section{MOENDER.}

Aan den binnenweg, die van Tempêh Oostwaarts aan naar Yossowilangoon loopt, in het Zuiderdeel van Loemadjang, staan, bij. de dessa Moender, onder een wringin-boom, drie beeldjes, vermoedelijk een Boeddha en een Doerga en Ganesa, zittende figuren. De herkomst, en de tijd sinds wanneer zij daar kwamen, wist niemand meer op te geven. De beelden en de plaats zijn kaulan, offerings-beloften-plekken. De afstand van Tj. Ngardipoero zal ongeveer vijftien palen Oostelijk zijn, van Koetoboro, negen palen bewesten.

\section{KOETO-BORO.}

(Verbeek n 684; Rapp. 1904 p. 140).

Roodbaksteenen ruïne; vorm onbekend.

Ligging, op den hoek van Poeger-Pliendoengan, tien of elf palen Noordwest of West-Noordwest van de negorij Poeger, nabij de dessa Kentjong. Van Loemadjang uit eerst elf palen Oost-Zuidoost tot Yossowilangoon-Keting, grens van de landschappen Loemadjang en Poeger; dan vier palen in dezelfde rigting van Keting tot bij Kentjong, dan eene halve paal Zuid, door wildernis. Linker, N.O. oever van de sterk om de Z.O. stroomende rivier Kali boto, K. Gantoeng.

In een ondoordringbaar glaga-bosch, waardoor twee paden loopen, beide Zuidwaarts naar Djeni. Ongeveer zes palen van de Zuidkust, het punt tegenover Noesssabaron.

Er zouden gevonden worden: muren, graven, gebouwen van 
rooden baksteen, alles zóó verlaten en onder beheer van tijgers, zwijnen, slangen, dat mij het onderzoek ondoenlijk was, 1861-3.

Er zouden weleer beelden hebben gestaan, die ook zijn ontvoerd geworden, naar Bezoeki of Probolinggo (opgave Augustus 1861).

\section{KROEKOEP.}

In het kustland van Djabong, maar Westwaarts op, beoosten Probolinggo in het distrikt Gending, bij de dessa Kroekoep werden vroeger roodbaksteenen grondslagen gevonden, fundamenten van muren, van gebouwen, waarvan de bestemming niet meer kan worden aangeduid.

Dit geheele kustland is sterk bevolkt, geheel ontgind sinds de laatste dertig jaren. Waar weleer de gebouwen stonden, wordt nu suikerriet geplant.

Ook in het meer Oostwaarts gelegene- distrikt Padjarakkan worden ruïnen, grondslagen van vroegere gebouwen gevonden, van rooden baksteen. De ouderdom zal evenwel vermoedelijk niet hoog opgaan, maar de aard en bestemming meer HindoeBoeddhaisch of Sivaitisch dan Mohammedaansch wezen. In deze streek werd het Mohammedanisme eerst laat, en dan nog verre van algemeen, ingevoerd; en de invloed van Blambangan was hier nog in 1710 volkomen.

KROETJIL.

(Rapp. 1904 p. 112).

Noordwesterhelling Yanggebergte. Van Padjarakkan uit Zuidwaarts, acht palen tot Tjondong, aan den Noordervoet Lemmongan. Dan vier palen Oost door bosch en wildernis tot Rogonina. Dan Zuidoost de glooijende berghelling op, langs de ravijnen der Rogonina-rivier, ongeveer tien palen.

Ook van Kraksan uit, acht palen Zuid tot Wangkal-passangrahan. Vandaar Zuid, de sterke uiterste voorsprongen van het Yanggebergte op, langs slingerpaden, voorbij en langs de plekken die Gadieng, Bangsri, Kroeboengan, Batoetobo, Bagor, Sewan, Pesâpen en Goeyangan heeten.

Kroetjil is een open vlakte in 't gebergte, waar hier en daar digt woud voorkomt. Men wees mij op een bergrug, Oost van den Passangrahan-hut, over eene bergkloof, waarin een tak der Goemarang-rivier vloeide, naar de Rogonina. 
Aan de overzijde der kloof, klauterende tegen de helling, tot op een vlak voorspringend punt. Daar stond, op een soort terras, een altaar onder een hoogen ouden boom, een vierkanten trachietsteen, van ongeveer drie voeten hoogte. Die steen was vroeger het voetstuk voor een ongeschonden vrouwenbeeld met vier armen, waarvan twee voor 't lijf, en twee opgeheven, tegen de ruggeplaat uitgebeiteld. Dit beeld stond gekeerd naar 't Westen, naar de zijde van den Lemmongan, en was door mijn geleider, op last van den tommongong van Probolinggo, weggenomen, en vervoerd naar den tuin van den Resident aldaar, waar ik het vond, - voor ongeveer een paar jaren geleden, ongeveer 1860 .

In de nabijheid stond nog een boeto, tempelwachter, met opgeheven knods, drie voeten hoog. De tweede wachter en vermoedelijk ook de Ganesa zijn die, welke te Wangkal Tenga voorkomen, en gevonden werden aan den voet van het gebergte.

De andere, vermoedelijk nog in deze digtbegroeide bergwildernis aanweezige oudheden, konde ik niet bezoeken bij gebrek aan geleiders. Hier en daar is heinde en verre een plekje in dit gebergte ontgonnen; maar menschen die konden en wilden medegaan, waren er niet.

De oude tempel Kadaton Koeripan zal ongeveer zeven palen rijdens Zuid ten Oosten van hier liggen. Kroetjil is ongeveer 3500 voeten boven zee. De top Argopoero is in Oost ten Zuiden, ongeveer vier uren hemelsbreedte.

Het vrouwenbeeld dat mij te Probolinggo aangewezen werd als van Kroetjil gebragt, was ongeveer vier voet hoog, ongeschonden, staande, een Parvati, Oema, Laksmi, Mahesvari of Mahadevi. Men had dit beeld eerst kort geleden gevonden, in de vroeger onbezochte bergstreek.

Of ergens een Tjandi was in deze oorden kon men mij niet zeggen. De pedestal geleek op een Yonistuk. Lingga vond ik niet. Sivavereering was zeker te stellen, Parvati was de hoofdgodin ter dezer plaatse, waar men alleen met klimmen en klauteren en kleerscheuren komen kan.

\section{BATOE-LANTJANG.}

De naam beduidt in 't Madoereesch, taal van den landaard in het land van Padjarakkan: lange steenen.

Dl. 72 . 
Gehucht van een paar huizen, Zuid van een tamelijk steilen, nu weinig begroeiden bergrug. Van Kroetjil uit slingerend OostZuidoost, langs Bermi-dessa; dan Oost-Noordoost, de ravijnen van de Rogonina over, bergvoorsprongen op, en nedergedaald in een kleine bergvlakte. Daar ligt Batoe-lantjang.

Tal van langwerpige bewerkte trachietsteenen. De grondslagen zitten vermoedelijk benedengronds. De weinige huizen waren eerst sinds eenige jaren geleden hier opgerigt.

Vermoedelijk stond hier weleer eenig gebouw. Nabij is een zeer enge passage langs een diepen ravijn van de Wangkal-rivier.

Beelden vond ik niet.

\section{TELOGO-INDRO.}

Noord-Noordwest-helling Yanggebergte. Een kwart paal Oost van het gehucht Palaussan of Plaussan, dat Noorderlijk van Pandanraras en Batoelantjang ligt.

Een digt begroeiden steilen heuvel, op den rand van een diepen ravijn van de Wangkal-rivier, en wel aan de Noordzijde. Het heuvelboschje was als afgesloten; rondom was het land kaal. Er moest voor de voet een pad in het gewas gekapt worden, steil heuvel op. De heuveltop, op ongeveer tweeduizend voeten boven zee, is een klein bergplat.

Er zijn een paar oude graven; een daarvan is bedekt met platte bewerkte steenen, trachietplaten, waarop twee opstaande platte steenen die teekenen van bewerking aanduiden (Lingamitisch).

Eenige Soekoe, voetstukken van houten pijlers van eenig gebouw dat hier vroeger stond, pyramidisch vierkant breed van onderen, dus bewerkt.

Een brokstuk van een gevormden waterbak, met ruw lijstwerk, soort van aarde, compakte lava-asch, zooals ik in Soemberwaroe veel vond, grijsgraauw, dof. De steenen waren blaauwgrijs, min of meer glanzig.

Eenige, vermoedelijk gehouwene, hoekige steenen.

Een gewezen vierkant, bedekt met vele ruwe steenen, vroeger de plaats van eenig gebouw. Twee ruwe hutten, met overblijfselen van vuur, met slaapbanken; plaats van offering en van belofte voor de bergbevolking.

De gidsen berigtten, dat hier vroeger beelden stonden van 
den vorm als apen of katten. Deze waren weggevoerd op last van een vroegeren kontrôleur Piet van Laren. De aanduiding van den vorm doet denken aan Ganesa en Mahadeva.

De gelegenheid is nog geene halve eeuw bekend; bevorens was alles hier onbewoond; in 1844 zelfs was de omtrek woeste wildernis.

\section{TELOGO-SARI.}

Anderhalve paal afstands ongeveer, Noordwest van Telogoindro. Een boschje, op den rand van de diepe ravijn, die naar het Noorden of Noordoosten afdaalt; ongeveer 300 voeten hooger gelegen dan Telogo-indro; digt begroeide wildernis; wortels, rottan, struiken, alles dooreen geslingerd, waardoor men alleen met kapmessen een ingang kan maken.

Midden in dit boschje vond ik platte, bewerkte, steenen grondslagen van trachiet, en soekoe, voetstukken voor pijlers van een gebouw, dat hier zal hebben gestaan.

Een stuk van een gevormde pot; bewerkte steenen, door boomwortelen uiteengewerkte massas steenen hoopen; alles op den rand van een steilte, die met het oog niet te peilen was.

\section{PASSAROEWAN.}

(Rapp. 1903 p. 40; 1904 p. 112).

H. N. Sieburgh, 1 April 1841, handschrift, berigt aan den resident De Vogel, uittreksel uit een algemeen journaal.

Over de kunstreizen van Sieburgh, kort verslag Javasche Courant $1847 \mathrm{~N}^{\circ} 25$.

"Gombong. Hoofdplaats Passaroewan, ouden naam.

In verschillende tuinen van partikulieren.

1. Oude heer Hofland, een uitsteekend schoon beeld, herkomstig van den berg Smeroe, van eene plaats waar anders geen spoor van een tempel gevonden wordt. Vorm: Ganesa. Staande houding (zeldzaam). Geheel gaaf, behalve één vinger verloren. Hoogte: niet opgegeven. (N.B. Meer beschadigd. De Vogel).

2. Residentstuin, drie voorwerpen.

De kop van een Gorgone of munstergod, als meer elders gevonden wordt, bouwkunstig versiersel. (Dus een kala). 
De staart of basis van een archivolte; symbolisch versiersel aan den voet van poorten en nissen van alle tempelen. Een olifantskop die uit den muil een leeuw spuwt.

Het derde stuk in de Residentstuin was een gebogene slangenkop, die als cariatide onder een consôle heeft gezeten. (Dus oeler Naga, trapstuk). Welligt een waterleiding, een tuit van een Yoni geweest.

3. Op het erf van den heer Dudman 1841. Een steen, waarschijnlijk van Singosari, inscriptie, even als de twee andere die nog te S. waren; een soort van karakters en versiering. Op beide vlakken en kant gemerkt, leesbare holgewerkte letters."

\section{Aanteekening $1868^{1}$ :}

In 1837 en later vond ik meerdere stukken ter hoofdplaats Passaroewan. De Resident Domis beminde de "roof der oudheden . Ganesa, Siva, Nandi, Naga kwamen meer voor. Vermoedelijk is er naar Banjoebiroe gebragt.

In 1868 vond ik in den Residentstuin:

Een Siva en een Parvati, p. m. $3 \frac{1}{2}$ voet hoog. Een Kala, een Naga, twee Ganesa, en een Nandi, met een paar verminkte. Van de Ganesa $\mathrm{N}^{\circ}$. 1 en de Batoetoelis $\mathrm{N}^{\circ} .3$ bleek mij niets meer in 1868, vermoedelijk naar Batavia vervoerd.

Ik vond nog: een Mahadeva, Boeto, alles vermoedelijk van uit het Malangsche, Singosari en van Dermo, Djedjawi. In den tuin, huis Prapatan: een Brahma, Vischnoe, Ganesa, één voet hoog zittende; een staande Mahadewa, een Nandi, ook zoo groot. De zittende Wischnoe met de lotusbloem in de open handen, zit als de Ganesa, niet als de Boeddha. Het voorkomen is zeldzaam. Van de vierhoofdige Brahma is een exemplaar te Soerabaya.

[Vervolg opgave Sieburgh].

«Tuinhuis Gading. Een halve paal bewesten de hoofdplaats P. ${ }^{2}$

1841. Woonhuis van den heer Cornelis Vos. Opgave, veel van Bali aangebragt.

Eenigen zijn inderdaad vreemdsoortig.

1. Een levensgroote Mahadewa, zeer beschadigd. Deftige houding en gestalte; hoogepriester of godheid; weinige versieringen, goede bewerking, tijd van hoog kunstvermogen.

1 Van Hageman zelf.

2 Thans in den Stadstuin. Rapp. 1904 p. 63 . 
2. Alle andere beelden van kleinen vorm, minder te herkennen aan attributen.

3. Een kleine vierhoofdige Brama, zeldzaam.

4. Wachters, van Indrokilo afkomstig, en uit kalksteen gehouwen, achteruitstekende hoofdtooisels (Vermoedelijk herkomstig van Tjandi Wayang te Singosari).

5. Basreliefs kennelijk van den Tempel van Dermo ${ }^{1}$. Roodbaksteenwerk.

6. Een aantal Dewi's en halfgoden.»

1868 Julij. Ik vond er op 17 Julij :

1. De Mahadewa, op een gemetseld voetstuk, nedergeslagene oogen, knevelbaard, beenbekleeding, gevouwen handen, ruggestuk deels weg, daardoor 't bijwerk ook.

2. Tweeëntwintig smalle, kleine, grillige Balische figuren, zwaar verminkt, zonder herkenning.

3. Twee bepaalde Siwa's, staande. De vierhoofdige Brama vond ik niet meer, welligt onder de nu geschondene, of weggezonden naar elders.

4. Deze twee gedrochten met knodsen, uitpuilende oogen, hurkend, waren er nog. Ruwe bewerking.

5. Van de rood baksteenen basreliefs vond ik er nog twee, kleine, verweerd.

6. Twee zittende Vishnoes, op lotusbedden, twee voet hoog; ernstige zedige houding, nedergeslagen oogen, Hindoesche physiognomie, sarongkleed, tiara, vrijwel bewaard.

7. Een bovendeel van een Vishnoe, vermoedelijk de in 1841 voor een Brama aangeziene; vorm en voorstelling als de vorige.

De vroegere eigenaar van dezen tuin heeft eenige dezer voorwerpen op moderne voetstukken geplaatst, in een soort van laan, nu weinig onderhouden. .

Losse voorwerpen verspreid.

Bij de bronwellen van Banjoebiroe zijn sedert 1832 een aantal voorwerpen, als sieraden overgebragt van elders, zoo als ik elders beschreven heb.

Bij de suikerfabriek van Kadawoeng in het land van Winongan, benoorden Banjoebiroe, staat een Boeto, wachterbeeld aan rugstuk, vier voet hoog, twee voet breed en dik, met breed krullend haar, hurkend, korte armen, de knods uit de

I D. i. Tjandi Goenoeng Gangsir. 
linkerhand gebroken. Vermoedelijk hierheen gebragt door den vorigen eigenaar C. Vos (1813-56). De herkomst onbekend.

Volgens de Jav. Cour. 1829 No. 57 en blz. 179 Pass. van Domis 1834, was deze streek toen nog boschrijk, en werden hier vele antieke steenen opgegraven. De overlevering stelt hier nabij den ouden zetel van Winongan.

Bij de suikerfabriek Gayam vond ik in 1868 op een sluisdeurtje staan, een kleine Siva en een dito Mahadeva, een voet ruim hoog, zeer ruw, verweerd tegen ruggestukken aan.

Bij Ranoekliendonang, gezegd meir van Grati, vond ik vroeger ook een paar beeldjes, van elders aangebragt ter versiering. Over dit meir zie men Jav. Cour. 1828 No. 142 en Domis, Pass. blz. 10 .

\section{TJABANG BAUËN.}

1859. In den omtrek tal van bewerkte steenen, sommige met letterteekens.

Vermoedelijk vroeger gebouw bij den waterval van Bauwen.

\section{TJANDI RAH-TAWOE.}

(Rapp. 1904 p. 49).

Aan de Noordoost-helling van den Indrokilo, Ardjoeno-gebergte, in de desa Rah-tawoe gelegen.

Daar vind men een-ingemetseld altaar, vermoedelijk een Yoni, met een opstaanden ronden steen, die Lingga-Tjandi wordt geheeten.

Opgave van den wedono, die $14 \mathrm{j}$. in dat distr. Porrong was, $1852-1865$, - in 1868 te Redjasa.

\section{BADPLAATS PAGER.}

Aan de Noordoost-helling Ardjoeno. Vóór 1852 nog een groot bosch, distr. Pandahan en Porrong; later dessa genaamd Pager.

Daar was weleer eene badplaats, vijver met ruime bronwellen. Door 't uitkappen van 't bosch droogden de wellen; en de vijver werd gedempt. In 1856 groef men den grond op, voor de steenen ten behoeve van den brug Toempeng, in den weg naar Malang-Passaroewan. Er werden veertienhonderd trachiet blokken opgegraven. Thans is niets meer op te merken, en alles veranderd (opgave wedono 1852-65). 


\section{DERMO.}

(Verbeek n 628; Rapp. 1903 p. 35; 1904 p. 27; 1910 p. 32).

\section{Sieburgh 1841 Ms. :}

«Een paal van den grooten weg af, in dessa, de schilderachtige Tjandi Dermo.

Van gebakken steen, van binnen nog geheel, en van dakwerk nog goed. Bouwkundige stijl $=$ slechte kunstsmaak.

Massief overladen met gevulde nissen, kleine basreliefs, rosetten, van buiten. Van binnen een vierkante gemetselde put, dus geene gelegenheid voor altaar. Om de put slechts een smallen rand, om rond te loopen. (Welligt een grafkuil, grafstede).

De manier van bouw, geheel afwijkende van elders, in bouwtrant. $\mathrm{Bij}$ andere tempels van gebakken steen is het geheel eerst glad voltooid, en zijn de figuren en relief uitgehouwen, bloembanden, arabesken, rosetten, in het vleesch van den steen. Bij Dermo zijn alle de opgelegde niguren afzonderlijke baksels. De tempel is er mede bekleed. Men kan er dus stukken afnemen. Te Gading zijn eenige dezer fragmenten.»

1868 Julij bezoek.

Ligging, aanduiding als in 1830 (Domis). Midden eener dessatuin, afgezonderd, omzuiverd.

Grondstuk, fundamentmuur, 19 passen van Zuid naar Noord en dito van West naar Oost. De latar, het trapterras, nog 12 pas Oost uitstekend. Hoogte geheel p. m. 25 voet, zeer begroeid.

Reliefwerk bijna geheel weg; aan de Noordzijde nog vijf vierkanten, niswerk; een boeddha zonder hoofd, twee schildpadachtige figuren, anderhalf voet vierkant. Lijstwerk bijna totaal onmerkbaar.

Onderst massief ongeveer 12 voet hoog; weinig pyramidiaal ingaande, en opwaarts inspringend. Door een opengebroken deel aan de Noordzijde is een binnenwerks hol te ontdekken. De tweede verdieping tien voet hoog, vierkant, smaller dan de onderzijde. De derde verdieping, kroonwerk, onkenbaar en ingestort, een paar voeten hoog.

Kleur van 't geheel, vuilbruin. De steenen van een paar span lang, op de breuk rood, vast.

De losgebakken figuren waarvan Sieburgh in 1841 spreekt, waren weinige meer in 1868 , misschien een twintigtal. Op de hoogte van tien voeten begint eene soort van opzettelijke uitbraak 
van steenen. Aan de Zuidzij is nog een enkele nisvorm, aan de Westzijde eenig lijstwerk op te merken. Aan de Oostzijde is een massive trap van baksteen, los op elkaar, tien voet breed, achttien voet vooruitsteekende, met een tiental uitelkander gewekene treden, en een soort portaal, voor eene poortopening van ongeveer acht voet hoog en drie voet breed. Die deur, poort, heeft lijstkozijnen van steen. De binnenwand is nog vast ineen, glad, twee voeten dik. De buitenwand alom uiteengewerkt en onregelmatig geworden door wortels en ook door schijnbaar geweld van buiten.

Op het basreliefẅerk vond $\mathrm{ik}$, zoo aan den wand van den Tjandi, als op den grond, en in den tuin van Gading:

Rosetwerk, bloemwerk, hartvormig lijstwerk van eenige gothisch arabischen vorm $=$ Ogiven.

Twee kennelijke Boeddhavormen, zonder hoofd; beenen kruisselings, voetzolen naar boven, regterhand op de knie, linker leerende opwaarts.

Twee rondvormige beelden als schildpadden of schildbeelden met lijstwerk.

Twee menschenfiguren elkander bestrijdende, de eene vierarmig, ruwe vormen in baksel.

Drie stukken van trachietsteen, waarvan kennelijk: een zoogenaamd Yoni-altaar, met rand en buitenlijstwerk, dwars door gebroken, nu als hoekstuk van een pad opgesteld. De kennelijke tuit, het vrouwelijk symbool, lag op een hoop baksteenen gestapeld op de Zuidoostzijde, tegen een boom, op het trapterras.

Een Lingga van een voet hoog, boven rond, onder vierkant, te klein voor de gebroken Yoni. Dus zal er nog een andere Yoni, een anderen Lingga geweest zijn.

Een hoeksteen van ongeveer een voet lang, los gewerkt, nu slechts opgestapeld; bewijs dat ook hier trachiet gebezigd werd als materiaal. $\mathrm{Al}$ het andere was rooden baksteen.

Op ongeveer honderd voeten Noordwaarts van de Tjandi vond ik een vierkante waterbak van Modjopaitsteen ingemetseld, en blijkbaar van overoude tijden; schoon Domis, Rengers en Sieburgh de bak niet aanduiden. Het water welde gering op, was troebel, de uitloop gering, doch er baadden kinderen in.

Daar juist de. G. G. Meyer in deze streek was, scheen daarom de omgeving schoon en opgeruimd te zijn; hier en daar een afgevallen steen opgesteld, zelfs onherkenbare stukken. 
Bij de Tjandi staan drie of vier oude Wringinboomen, waarvan één eenige steenen omklemd hield; bewijs voor ouderdom. Twee dier boomen staan op het beneden voorportaal, de lataran, het terras. Beeldwerk van trachiet is er niet meer.

Van de Noord, West en Zuid is het geheel een vervallen, pyramidialen steenklomp, als uitgevreten, erg pokdalig, ontwricht, begroeid, kolossaal.

Het binnenste van het basement te Dermo schijnt hol te zijn; de zoogenaamde onderkamer volgens Domis, 1830. Van dat opene binnenwerks bleek mij uit eene kleine opening, gemaakt aan de Noordzijde door schattenzoekers. De wand is daar ongeveer twee voet dik, maar de ruimte is met ingevallen steenen opgevuld. Vier voet ruimte, beweging met een stok, was vrij van aanraking.

In de poortopening aan de Oostzijde hing een gordijn van eenmaal wit geweest zijnd lijnwaad, even als voor den ingang van elke grafstede; ook Mohammedaansch mudern. Dermo is een Kaulan, plaats van geloften, wenschen, offers. Ik vond er vrouwen bezig voor natuurlijke wenschen bij den Lingga en Yoni.

In de omgeving vond ik geene blijken van bijstukken, onderhoorige gebouwen, behalve de badplaats, die ongeveer achthonderd vierkante voeten beslaat, zonder eenige versiering, hier en daar de wand reeds ontwricht, uitgebroken, weinig hoog of diep.

\section{INDROKILO.}

(Verbeek n 622; Rapp. 1904 p. 48).

In 1831 liet Domis te Passaroewan een stukje drukken, getiteld: Ardjoeno en Indrokilo, waarin hij zich zelf als den bezoeker van die oudheden aanduidt. Hij zelf was echter te corpulent om de naauwere poorten doortegaan. De bezoeker was zijn zoon.

Sieburgh geeft van zijn bezoek in 1841 het volgende op:

«De meest onbezogte tempel op Java is waarschijnlijk die van Indrokilo. Op een aanzienlijke hoogte van het Ardjoenogebergte gelegen. De bouwval beloont de moeite niet. De nadering is ongemakkelijk. Het is een tempel gewijd aan Lingam en Yoni.

Deels van gebakken steen, deels uit hardsteen opgebouwd. De tempel, de bordessen, de trappen en terrassen en de vele beelden zijn volslagen miniatuur. De beelden doelen alle op de 
progeneratie en conjunctie, echter nog met zekere zedigheid voorgestelt (Dus als op Soekoe en Tjetto).

Op de verschillende terrassen die men moet beklimmen voor de nadering van dezen tempel, zijn watervaazen in den grond gemetseld, van gebakken steen.

Te Gading bij Passaroewan zijn wachters of Boeto van hier, Indrokilo, afgehaald.»

\section{BADPLAATS BANJOEBIROE.}

(Verbeek n 630; Rapp. 1904 p. 87).

Eerste berigt 1819. Verhuell, Herinneringen II, 95.

1860 - 1868. Een breede vierkante, met gehouwene steenen ingemetselde rijke wel, in een klein dal. Omgeven door het overblijfsel van een oorspronkelijk woud, zwaar geboomte, met een kolonie van grijze apen. 1829 reeds zoo. Eerst in 1847 deed de heer Hofland hier een steenen badhuis bouwen.

Rondom den vijver, de vierkant ingemetselde wellen, staan voorwerpen die oogenschijnlijk van elders zijn aangebragt.

1. Een grooten, vier voet hoogen steen, met bijna verweerd inschrift in kleine karakters voor en achter, ongeveer als die van Siempang.

2. Een trog, waterbak, zes voet lang, twee à drie breed, drie à vier hoog, één steen.

3. Naga, slangenkoppen, trapstukken of waterleiding, ongeveer zes voeten lang, een half dik, minder fijn bewerkt.

4. Een paar Ganesa's, silo, een van vier voet, de andere kleiner; bewerking als voren.

5. Een paar Siwa's als boeteling en als Mahadewa, twee- en vierarmig.

6. Een paar Parvati's, deels geschonden, een half afgebroken, een paar voet hoog.

7. Een paar fragmenten van dieren, Nandi, Singha, Naga; een hoop baksteen, fundament of muurwerk; eene Boeddha-voorstelling.

Alles van de ligtgrijsgraauwe trachiet, die in Oost-Java meer algemeen is, en in bergkloven en rivierbeddingen gevonden wordt, van andere kleur en constructie als de blaauwgrijze in Midden-Java. Alle de beelden op voetstukken, vast, en aan rugstukken, uit één en hetzelfde stuk. De bewerking minder edel, minder zuiver als in Midden-Java; doch alles schijnbaar verweerd en door transporteeren geschonden. 
Eene Boeddha scheen van een eigenaardige sekte te zijn; tiara, slagband, handen op de knieën vast, ruw bewerkt, wezentrekken geschonden.

De trog, bak en Naga zijn vermoedelijk die, welke in 1838 gevonden werden aan de Westelijke helling van den Smeroe, voorbij Loemadjang Tengga, in het woud "Soengi petoeng»; T. N. I. VI, III, 159. Zijn dus uit Zuid-Malang.

Volgens Not. B. G. IV, 208, 247, werden in 1867 antike voetringen gevonden bij Banjoebiroe.

Volgens Buddingh zouden de beelden uit Malang herkomstig zijn. Hij vond ook Banaspati, Kalahoofden, waarvan er een reusachtig groot nu nog voorkomt, 1868 .

Alles is er sedert 1829 gebragt, want Domis noemt enkel een onbewerkten offersteen, die er nu nog is, doch in den grond zit, - een kaulan voor hoopende vrouwen.

Tijdens een laatst bezoei op 30 July 1868, heb ik opgenomen en opgeteekend, de rondom de badplaats staande beelden, die daar gebragt, en van elders gehaald zijn geworden.

Een Siva als boeteling, met trisoela en kruik in de linkerhand, twee en een half voet hoog, tegen een ruggeplaat, driekwart uitgewerkt, ruw.

Een Siva, beeld van twee voeten, als de vorige, maar meer beschadigd, op voetstuk.

Een Parvati, met vier armen, van anderhalf voet hoog, met lotus, glorie.

Een Parvati, kleiner, meer geschonden.

Een Ganesa, van $2 \frac{1}{2}$ voet hoog, met gebroken ruggestuk, ruw bewerkt, voetstuk, glorie.

Een Ganesa, van twee en een half voet, snuit afgebroken, voet en ruggestuk.

Een Ganesa van twee en een half voet, compleet met voet en rugstuk.

Een Doerga van twee en een half voet, voetstuk, Maisjasoera; defect.

Een klein Kalahoofd, met verlengstuk, achterwaarts als trap, vijfkwart voet hoog, twee diep.

Een groot Kalahoofd, op een soort altaar of voetstuk van $3 \frac{1}{2}$ voet hoog, en 5 voet breed en lang; kolossaal, als die te Kidal, Kraksan, Padjarakkan. 
Een ornamentstuk als kalahoofd, doch rosetachtig, met een beeldje er in, rond; één voet.

Een Bodhisattwa met tiara, hals, armbanden, lotus; zittende; twee voet hoog.

Een half-onderdeel van een soort Mahadeva, lotus, gada, voetstuk, twee voet.

Een doorbroken, beschadigde Parvati, staande tegen een boomwortel, met straalkrans, vier armen, 2 voet hoog.

De batoetoelis, staande beschreven steen; bovenzijde met bloem- en rosetwerk uitgebeiteld, verder met ingehouwen letters, vierkante karacters, kleiner als die van Singosari en Siempang, $3 \frac{1}{2}$ voeten hoog, twee voeten breed, vier duim dik.

De trog, steenen vierkanten bak uit één stuk, twee en een half à drie voet lang, anderhalf voet breed, drie voeten hoog.

De Nagakoppen, twee en middenstuk, beide koppen naar buiten gekeerd; soort van deksel van de steenen bak.

De offersteen is een aan de Noordzijde in den grond liggende reusachtigen trachietsteen, waarop een klein vierkant van kleinere steenen, en twee grootere, opstaande steenen, die tusschen beide eene opening laten van een paar duim. De eene steen is hooger dan de andere. Ruw, onbewerkt, poreus. De voorgewende heiligheid laat zich verklaren door den vorm, die op een Yoni gelijkt, het zinnebeeld van vrouwelijke teelkracht, en de opstaande, groote en kleinere steen.

Nabij en bezuiden de bronwel en plaats, op de aanhoogten treft men reusachtige in den grond begravene steenklompen aan, waaruit nu nog voetstukken, soekoe, gehouwen worden. De steen is van dezelfde soort als waarvan tempel en beelden zijn. Onder water schijnt hij gemakkelijk te bewerken, en verhardt in de open lucht (11 Aug. 1868). Nader berigt stelt die gehouwen steenen als van vroegeren datum aanweezig geweest.

\section{TJANDI PARI.}

(Verbeek n 496; Rapp. 1903 p. $56 ; 1905 / 6$ p. $97 ; 1910$ p. 33).

Door mij bezocht en het eerst beschreven, 1851, T. Bat. Gen. II, 394; Notulen II, 230.

Gelegenheid. Paal 26 Zuid van Soerabaya; eerst Zuid tot Porrong, dan West tot Katapang; op den weg naar Krembong; dan een paal ongeveer Noord van den weg af, naar de dessa 
die den naam voert van Tjandi Pari. De derde post van Soerabaya, paal 17-18 en ook eene suikerfabriek en dessa heeten Tjandi, doch daar is enkel de naam overgebleven.

Voorkomen. Te midden van de groote dessa Tjandi Pari, stonden drie kolossale, vierkant, bijna kubusvormige, roodbaksteenen, pyramidiaal opgaande gebouwen, ongeveer als de Tjandi Brawoe en $\mathrm{Tj}$. Ngartipoeri.

1. Onderdeel vierkant voetstuk met lijstwerk, uitstekend regthoeking zonder bloemornament, deels uit den grond gegraven, tot op een of twee voeten diepte, ongeveer 50 voeten elke zij. en tot zeven voeten hoogte. Aan de Westzijde een soort van trap, nu onder uitwerpselen van vledermuizen bedolven.

De tweede verdieping, boven dit voetstuk, is ongeveer 25 voeten hoog, regthoekig vierkant, buitenwerks aan den Zuidoost- en Noordkant met lijstwerk, uitgewerkt in de rooden steenmuren. De Westkant heeft een ingang, klein portaal, trap, drempel, zonder kozijnen of posten.

De derde verdieping is de pyramidiaal opgaande en in een punt uitloopende dekking, ongeveer $15-20$ voeten hoog.

Uit- en inloopend regthoekig lijstwerk, zonder beeld of bloem of krulwerk.

Binnenwerks. Een vierkant vertrek, met een gat in den grond in 't midden, evenals Tj. Ngartipoeri. De wanden wemelende van duizenden vleermuizen, wier uitwerpselen voeten hoog den binnengrond, de put, de trap, het portaal bedekken en opvullen, en waarvan de scherpe reuk veel van de opmerking ontroofd.

2. Als een uitgeteerd deel van den vorigen vorm, op het invallen, de top reeds ingestort.

3. Eén enkele puinhoop, op eenigen afstand van de vorigen.

Dat deze ruïnen vroeger nog al bezocht zijn, duidt de opgave aan, van de menschen ter plaatse, de opgave op de kaart van Le Clercq, en de zeer onjuiste mededeeling van Buddingh, in zijn prachtwerk N. O. I. 1859, I, 353. Maar de beschrijving door $\mathrm{mij}$, is de eerste bekende.

Allerwege in die dessa Tjandi Pari, en langs de paden, zijn de helderroode baksteenen verspreid bij groote menigte. De nabijliggende suikerfabriek Watoetoelis is deels van den afbraak dezer Tjandi's gebouwd.

In 1864 werden bij Tjandi Pari en omstreken eenige beelden gevonden. Daarbij was een Boeddhakop. 
SOERABAYA.

(Verbeek n 440; Rapp. 1903 p. 55; 1907 p. 201).

1. De Djoko-Dolok.

Vóór het Residentiehuis te Siempang, bezuiden, en in een soort tuin, vroeger een pleintje, vond ik reeds in 1837 een kolossaal Boeddha-beeld, op een lotuskussen, en op een vierkant voetstuk van vijf voeten hoog; 't is er nog 1868 . Het beeld is dubbel levensgroot, welgevormd en wel geproportioneerd. Het kussen is rondom met drie regelen kawikwadraat ingegrift; duidelijke letters van een duim groot. ${ }^{1}$

Rondom stonden vroeger een twintigtal beelden, voorstellingen van de leer van Siva, Lingam, Yoni, Singa's, Mahadewa's, wachters, Boeto, Raksasa. De schoonste heb ik opvolgende naar 't Museum Bat. Gen. gezonden.

Drie groote, vijf of vier voet hooge, een kwart of meer dikke, twee voet breede, opstaande steenen, smaller van onder als van boven, en puntig, driehoekig, stonden vroeger daarbij, later in den tuin, en zijn door mij vervoerd naar den konstruktiewinkel, ter afdruk in ijzer. Zij zijn nu te Batavia (Bat. Tijds. XII, 174; II N. IX, IV N. 207). Van boven tot onder, voor en achter, en op de randen, ingegrift met dezelfde kawikwadraat letters, als op de zitting van den Boeddha, als op een steen bij Singosari, en als op een dito bij Banjoebiroe. De ontcijfering duurt reeds eenige jaren. $\mathrm{Zij}$ zoude te Batavia geschieden door Friederich.

Alle die beelden van Siempang zullen van Modjopait en Djelotoendo hierheen gebragt zijn, tijdens Bezier-Domis, 1825-31.

De Hindoebeelden, die ik opvolgende gevonden, en van hier verzonden heb naar Batavia, zijn geweest voorstellingen van:

Siva-mahadeva, boeteling, éénhoofdig, meerarmig.

Parvati-sri-mahadevi, meerarmig.

Ganesa, zittende, meest geschonden.

Boeddha, groot en klein, leeraar, Boedhisattwa.

Brama, klein, vierhoofdig.

Naga, serpentenkop, trapstuk of leiding.

Kala, Banaspatti, Boeto, knodswachters.

Singga, leeuwenkoppen en ligchamen als priapus.

1 Zie Prof. Kern in Tijdschr. Bat. Gen. 52 (1910) p. 99-108; vgl. Oudh. Versl. 1913,2, p. 33 en 1914,4 , p. 206. 
Hondsvoorstellingen zittende met priapus.

Inscriptie-steenen, randen, bloemwerk.

Alle van gehouwen steen, trachiet, welligt vormwerk, grijs, grof korrelig.

De plaats is een offerstede, vooral voor hoopvolle vrouwen, die hier om vruchtbaarheid komen, wierook branden, bloemen brengen, en handtasting van den Linggam-priapus oefenen.

Een steenen stijl als een scherm achter en over 't beeld is er door onweder afgeslagen. Een der lange ooren werd door een pistoolschot, bij weddingschap, afg. in 1848, door den Resident Pietermaat, die drie dagen later stierf.

2. Ouden Dalem kadipaten, 1845 vernield.

Goetji, steenen waterpotten.

Nandi, zittende gehurkte stier.

Ganesa, olifantskop en snuit.

Siva-Mahadeva.

Sri-Parvati.

3. Klinting, Chineeschen Tempel.

Voorzijde. Een Boeddha-Siva, van een half voet.

Achterzijde. Een Doerga op de Nandi, met acht armen, een voet hoog, zeer zuiver. Maisjasoera.

4. Bij Han Kok ping, Petoendjoengan.

Een groote waterbak met jaartal-inscriptie. ${ }^{1}$

Eenige Boeddha's, Siva's, Ganesa's, Sri.

Koperen munten of penningen van Modjopait.

Een offerbeker, als die van Tengger.

Zwijnen, ossenhoofdbeelden, veelsoortig, pyramidiaal opgestapeld.

5. Bij I. W. B. Wardenaar.

Een levensgroote Sri, Laksmi of Parvati. ${ }^{2}$

Een dito Ganesa, vroeger in den ouden Dalem, later door mij van Sawaän-Ondo gehaald.

De urne van Djeloktoendo, met inhoud. ${ }^{3}$

Inscriptie van Djeloktoendo.

1 Zie Notulen Bat. Gen. 1905 p. 96 ; Rapp. 1907 p. 196; Not. 1909 p. 134; 1911 p. 147 ; 1912 p. 55 en CXXXIII. De verzameling, later zeer uitgebreid, is verkocht; een deel thans in het Museum te Batavia (Not. 1893 p. 59 en Bijl. XVIII; 1905 p. 100, LIII-LXIV en Bijl. XIII).

2 Over dit beeld, thans in het Museum te Batavia (Groeneveldt, Catalogus p. 94) zie men het artikel in Tijdschr. Bat. Gen. 54 (1912) p. 470-485.

s Thans eveneens te Batavia; Notulen 1869 p. 22 ; 1879 p. 85 ; Groeneveldt p. 120 en 215 , met noot van Brandes. 
Een paar Boeddha's en massive banken.

Een stijl van de bidstoel van Browidjoyo, van hout uitgewerkt, met inscriptie. ${ }^{1}$

Een phallus Linggam en Yoni altaar.

6. Ten huize van I. Hageman J.C.z. 1868 over:

Een groote Parvati of Laksmi, vier voet hoog, geschonden, en tegen een ruggestuk.

Een kleine vierhoofdige Brama.

Een kleine Siva Mahadeva als boeteling.

Een Boeddhisattwa leeraar.

Twee kleine wachters, Boeto.

7. Elders tal van voorstellingen van:

Siva als Mahadeva als boeteling, veel.

Sri-Parvati-Laksmi, staande, veel.

Doerga op den Maisjasoera, weinig.

Ganesa de olifantskop, meer.

Boeddha, de leeraars en leerlingen.

Goetji, potten, vaatwerk.

Brahma, vierhoofdig, zelden.

Ornamentwerk, rosetten, hoofden.

Lingams onder verschillende vormen.

Yoni's als altaren en waterleidingen.

Nagakoppen.

Kala-Banaspatti-koppen.

Dit alles is vermoedelijk ontvoerd van de tempelen in de Delta, van Modjokerto, van uit Malang.

\section{SINGOSARI.}

(Monographie van Brandes, 1909).

Ms. Sieburgh 1841. Eigen bezoek 1842-1862.

1. 1841.' Van den ouden zetel van Singosari, thans bij Glandang voorkomende tusschen Lawang en Malang, vond Sieburgh aan te duiden, vijf bouwvallen van Tempels. De stijl en de uitvoering, duidt aan een schitterend tijdvak voor kunstkennis en hindoe-wetenschap (zie onder). Ook van verschillende tijdvakken. De inlander onderscheid die deelen niet bij afzonderlijke namen.

1 Zie Verbeek no 471; ook volgens Brandes is het jaartal 1487. 
Eene enkele, aan de zijden met basrelief bedekt, heet Tjandi Wayang. Het maaksel der beelden is onvolmaakt, zoo dat er veel overeenkomst is met Wayang figuren.

Grondstof. Tjandi Wayang is van zeer poreuzen witten steen, die zich gemakkelijk laat snijden. De uitvoering en stijI duiden zwak kunstvermogen aan. (Eerst zeide Sieburgh het tegendeel boven). Of het een bewijs is voor de kindsheid der kunst, dan wel voor de verbastering van later tijden, is niet te bepalen.

2. Nabij Tjandi Wayang ligt een groep van drie bouwvallen. Zij liggen wel op ééne lijn, maar zijn niet als één bouwkundig geheel aan te nemen.

De eerste bouwval is de basis van een gewezen gebouw, met een vooruitspringend terras. De vorm van een ingedrukt voetstuk. Met kolossale parelbanden omvat. In die parelbanden en aan de dekstukken der kroonlijst, reliefwerk.

Kolossale bouwtrant, trotschheid van aanzien van dit werk, indrukmakend.

Bewijs of vermoeden voor de grootschheid der vroegere volvoering.

3. Nabij de Tjandi Wayang, het tweede stuk. Een tempel van een veel minder schoonen bouwtrant. De vorm is een voetstuk, met uitspringende nissen op ieder vlak, staande op een hoog blok als basis. De concaviteit dezer tegenwoordige ruïne was vroeger bedekt met een koepeldak, dat puntig pyramidiaal uitliep.

Dit gebouw vormde echter vroeger waarschijnlijk geen schoon geheel. Het was te zeer gedrukt, beroofd van alle evenredigheid, spherische eigenschap, zonder die esthetische waarde, zonder die bouwkunstige regelen, die voor het schoone gevorderd worden.

Uitspringende vleugels. Een dier vleugels is met den tempel verbonden, daar, waar ook de ingang voorkwam.

4. Nabij de vorigen een onkennelijken, vormloozen steenhoop. Had ook vooruitspringende vleugels, even als de vorigen. Het doel dezer vleugels kwam Sieburgh niet duidelijk voor.

5. De Tjoengkoop, Tjoemkop. De eerste bij de nadering der ruïnen. Iets kleiner in omtrek dan de vorigen. Sierlijk van vorm, uitmuntende.

Vier vooruitspringende kapellen, vormende een grieksch kruis, Torschende een vierkanten dom, met uitspringende nissen. Hoogte 9.41 ellen $=30$ voeten. Bekroond door een pyramidiaal dak. 
Het geheel heeft iets sierlijks luchtigs.

Deze tempel bevat een heilig deel, een heilige der heilige, sanctum sanctorum, drie buitenkapellen. Deze kapellen bevatten godenbeelden. Daarvan was nog maar één op de plaats aanweezig. Vermoedelijk een Mahadewa-voorstelling.

Gorgonenkoppen boven de poort, en de ingangen der kapellen. Deze zullen niet volmaakt, niet voltooid zijn, zoo als het voorkomt.

De fondamenten van baksteen (1839, V. Nes).

Domis geeft een afbeelding (Pass. 120-121). Dit plaatje is van veel waarde. In $1842,1845,1861$ vond ik ủe omgeeving bebouwd, bewoond.

Op het plaatje staan nabij den tempel geteekend, als opgesteld:

Vier groote Ganesa's.

Een groote Mahadewa of Doerga.

Een kleine Nandi.

Een kleine Soerio, zonnekar.

Een wachter.

Een Linggam.

Deze heb ik in 1862 deels nog teruggevonden. Deze waren bevorens naar Malang vervoerd, en zijn er door Domis teruggebragt (Pass. 121). Domis deed de geheele stede opruimen, schoon maken, zuiveren (ibidem).

6. De ingang van een gewijd centrum, uit het aanweezen van twee kolossale wachters af te leiden (1820 in de wildernis liggende). De twee wachters zullen van de voetstukken gezakt zijn, op de plaats waar zij oorspronkelijk zouden hebben gestaan. (Opgerigt 1815, 1829).

Kolossaal als beeldwerk. Welgekonserveerd. Uitmuntend uitgevoerd, bewerkt. Zittende houding, op ééne hiel. Gewapend met beukelaars, een regts, een links. Versiering uitsluitend slangen en doodshoofden. (Raffles zoude de eene hebben opgerigt).

Sieburgh kende twintig kolossale beelden wachters op Java in gelijke houding en vorm. Deze waren de bestbewaarde, grootste, het best bewerkt; 10 voeten breed, 12 hoog.

7. Uit de omliggende oorden hier vereenigd:

[Volgt een overzicht der losse beelden, in overeenstemming met het van elders bekende]. 


\author{
MALANG. \\ (Verbeek nº 615; Rapp. 1902 p. 255).
}

Tuin van den Assistent Resident, 1841.

Brahma. Levensgroot, wel verminkt, doch in geheel. Van de vier aangezichten was nog enkel het achterste herkenbaar. Van de vier armen twee overig. De verminking vermoedelijk niet door geweld en moedwil, maar door ongeluk, instorting van een gewelf. Alle de deelen die aan den muur geëndoceert geweest waren, bleven onbeschadigd. De bewerking uitneemende geweest. De goddelijke glorie nog als uitstralend.

Een groot Boeddha-beeld, kolossaal. Bijzonder schoone bewerking. Bijzondere conservatie. Kaalgeschoren kruiri, dus geen kroeskrullend haar, of lang, in vlecht of tros opgebonden. Dus eenig in voorstelling en soort. Zal vermoedelijk behoord hebben tot een kolossaal tempelgebouw, zoo evenredigheid is aantenemen.

Een levensgroot, zeer verweerd, en onkennelijk geworden beeld. Vier armen en een hoofd. De bepaling onzeker. Vermoedelijk een Wisnoe.

Eene kolossale inscriptie, weinig leesbaar (vermoedelijk van Djago gebragt).

Een kleinere inscriptie, bol gewerkte karakters.

Een aantal beeldjes van gehouwen steen. Volborstige vrouwelijke, 2 à $2 \frac{1}{2}$ voet hoog.

Hoofdplaats Malang. Vermoedelijk weleer hier een roodbaksteenen tempel aanweezig geweest. Bouwkundige fragmenten van die stof kwamen nog al veel voor, nog in 1841. Ook kleinere gebakken beeldjes.

In den tuin van den Assistent Resident:

Twee waterspuitende dewi's, gebakken steen.

Eene Ganesa, ook van gebakken steen.

\title{
DJAGO-TOEMPANG. \\ (Monographie van Brandes, 1905).
}

H. N. Sieburgh Ms. 1841.

Pittoresk door ligging te midden van een woud, omgeven van de weeligste groeikracht. De wanden des tempels zijn omklemd, en doorwortelt, door boomvezels. Het bovenste deel 
is daardoor geligt, en achterwaarts over, ter neder gestort. De groeikrachten alleen schijnen hier vijandig te zijn geweest.

Het voetstuk was bedolven onder afgevallen steenen, achter, en op de zijden. Men meende onder die afgevallen puin veel te zullen kunnen vinden, 1841, onder anderen de vier Gorgonenkoppen, Kala. Een dezer, van buitengewoone grootte, zat boven den ingang.

[Drie beelden van eenigsinds kolossalen vorm in de buitennissen. Een staand man, met langen baard, met bidsnoer in de regter, waterkruik in de linker hand, gewapend met drietand, trisoela. Sieburgh meende een Mahadewa. 't Is Siva als boeteling. Het tweede beeld, een kortlijvig man met een olifantskop, dus Ganesa. Het derde beeld, Doerga, gezegd Loro Djongrang, een vrouwenbeeld met acht armen, staande op een os, verdedigende den dwerg Oesoor, zeker de meening van de overwinning op Maishasoera, den hemelaanvaller. Acht armen duiden de volle kracht van haar vermogen aan. Geen enkele levensgroote Doerga voorgekomen aan Sieburgh in Passaroewan '].

De hoofdgodheid, op het bovenste deel des tempels gesteld, was wel omgevallen maar lag er nog. Het was eene voorstelling van Siva. De bewerking moet buitengewoon zuiver, edel, keurig zijn geweest. Doch de beschadiging is groot. Handen en armen zijn van een zeer schoonen vorm en beweeging als er aan Sieburgh immer voorkwam.

De tempel is op een eenvoudig plan gebouwd, maar van hooge complicatie in de uitvoering. De schoonheid der Hindoesche bouwkunde moet zich hier geheel ontwikkeld hebben, in aard en vermogen.

De tempel is drie etagen hoog, massief zonder ingang, even als Panataran. De twee onderste hebben een vooruitspringend terras aan de voorzijde. Daarheen leiden twee trappen. De bovenste etage was welligt een offeraltaar, voor Siva die daar stond. De drie verdiepingen hebben breede kroonlijsten. Beneden herhaling der kroonlijst in renversale rigting naar Indische bouwtrant.

Ligte sprongen breken het vierkant der grondvlakte. Die sprongen zijn verschillend van profil. Een rijkdom van gebroken

1 Deze geheele alinea behoort klaarblijkelijk niet in de berschrijving van dezen tempel thuis. 
horizontale lijnen, en eene zoo groote aan confusie grenzende menigte van gedenteleerde hoeken. Exagaratie in den vooruitspring der voorhoeken, kroonlijsten.

Het gevoel wordt alleen bevredigd door overtuiging.

1845. Mijn eerste bezoek. Bat. T. I, 62 [waarheen verder verwezen wordt].

\section{TJOEMKOP KIDAL.}

(Verbeek no 615).

Zes palen West van Djago. Beoosten den breeden heuvel Boering. De meest ongeschondene tempel van Java. Doch de beelden zijn er uit weggevoerd naar elders. Zedige bouwtrant, op het eerste gezicht opvallende.

De plaats, ligging is min of meer gezonken, volgens primitiven aanleg reeds. De ringmuur in dezen lageren grond, duidt de oorspronkelijke bedoeling aan.

Voor den ingang staat een kolossaal voetstuk of altaar, breeder dan de tempel zelve is. Naar den top van dit altaar leidden twee trapjes; een is nog overig.

De tempel zelve is zuiver vierkant, enkel met de vooruitspringende trap van den ingang. De nissen in den buitenwand zijn niet relief, meer dan de voorsprong der kroonlijst. Het kroonwerk is van pyramidalen vorm; rijst van de eerste uiterste lijn van het dakstuk naar boven. Deze pyramide is gecomposeerd uit eene opstapeling van kleine piedestals, die in getal verminderen, en aan den top in éénen enkelen uitloopen.

Alle overlading van versiering is hier afweezig. Een enkele breede bloemenband omgeeft het gebouw. De dekstukken der basis worden door Leeuwen als cariatiden gestut. Kroonlijst zonder architraaf, zonder frise, slechts gecomposeerd uit beneden sprongen, en ogiven, een schoon geheel vormende.

Rijke voorstelling van lijnen, genoeg voor schoonheid, zonder . andere versierselen, en toch vol zwier aan 't gebouw. De kiesche luxerieuse manier bij Kalibening en Tjandi Sewoe in MiddenJava voorkomende, is evenwel in Oost-Java niet te vinden. Hier is de leer der Estetica minder opgevolgd.

Tot zóó verre Sieburgh, 1841.

Mijn eerste bezoek: 1845. Bat. Tijds. I, 64 [waar men verder zie]. 


\section{SINGORITI.}

(Verbeek no 602; Rapp. 1902 p. 315).

Postpaal 14 van Malang, voet van het grensbergland van Radjekwessi. 3000 voeten ongeveer boven zee. Omsloten door steile, kale bergwanden, als in een kom, uiterste voorsprongen van den Kawi-Panderman. Twee palen West van de negorij Batoe.

Twee opene bronwellen van warm en van koud water, omsloten door vierkant trachietsteenwerk, een tempeltje, thans geheel vervallen, - 1825 (Jav. Cour. No. 24) en 1799 (Rapport Ysseldijk) reeds evenzoo als in 1865.

Oorspronkelijk acht of tien voeten hoog, zonder uitwendige cellen, maar met beeldwerk in nissen. Een paar beeldjes nog aanweezig; 1865.

Grondvlak vierkant; de heele oxydeerende wel opgebroken, afgeleid en okergeel alles kleurende.

De wellen schijnen te zijn ingemetseld, en opgewerkt tot in een bad, dat vermeld is. Sanitarisch en Devoot gevoelen was dus hier reeds in overoude tijden zamengaande.

\section{LOEMADJANG-TENGA.}

Zuider- en Oosterdeel land van Malang. Reis naar den Smeroe, Jav. Cour. $1836 \mathrm{~N}^{\circ}$. 73. 3 Augustus 1836, van Boeloelawang uit. Tijds. Ned. Indië 1844 , VI, III, 159.

De reizigers waren I. F. W. van Nes, A. C. Schonck, W. Dickelman en A. J. v. d. Poel.

Donderdag 4 Aug. van Lemadjang Tenga, door de rivieren Pamotan, Lepoer, door wildernis, waar in 1832 een voetpad gekapt werd. Vervolgens door de kali Padang, Pringapoes, tot de wildernis: Oetan Soengi Petoeng.

Vonden aldaar, op een heuveltje, regts van het uitgehakte voetpad:

Een beeld, vier voeten hoog, twee do. breed, zijnde een staande Ganesa. Twee losse versierselen in steen, vermoedelijk van een tempelingang.

Verder op: vier graven, waarvan een met een beschreven steen, pyramidiaalvormig plat opgerigt, staande. De graven gewoon Javaansch.

Iets verder, een steenen waterbak, geheel ongeschonden, 
vier voeten lang, een voet breed, twee voeten hoog. Een uitgehouwen steen, voorstellende twee dooreengeslingerde draken, waarvan de koppen aan beide einden, drie steenen. Vermoedelijk de deksel van die waterbak geweest.

In de nabijheid nog: een staanden steen, hoog vijf voeten, breed tweeëneen half, dik drie duim met opschrift in letters als kawi.

Alle deze voorwerpen zullen vermoedelijk nu staan bij Banjoebiroe-Blaauwwater, waar ik ze vond. De plaats van vondst is, aan den Westelijken voet Smeroe, aan de Djoerang Sonosekar, Soemberbakar, kali Prengapoes, linkeroever.

Dezelfde weg werd door Junghuhn gemaakt 1844, "T. N. I. 1849, I, 118; Java IV, 746-782. De oudheden waren toen van daar reeds vervoerd.

\section{NGENDAT.}

1825 Reis 2 Luit. Jav. Cour. 1825, №. 24.

1839 Burer, mededeeling. Bianglala I.

Bij de dessa Ngendat, op den weg van Malang naar Batoe. Overschot van een vroeger tempeltje, trachiet of gehouwen steen (1839); midden in de wildernis, klein en ingestort (1825).

Ik heb er niets meer van gevonden, 1862.

Indisch Magazijn 1825 (1845) $\mathrm{N}^{\circ}$. 65, overgenomen berigten.

\section{BEDJI.}

Vermoedelijk Ngendat, hiervoren, op den weg naar BatoeMalang, poststation.

Stukken bewerkte trachietsteenen, en een beeld, gezien door een reiziger '.

\section{WEDON.}

Schill, 1842, T. N. I. IV, II, 46.

Eigen bezoek, 1844, 1863.

De Passangrahan van Lawang, de trappen vloer, stoep, zijn van gehouwen bewerkte trachietsteen. Die steenen zullen daar zijn gebragt van elders, en wel van Wedon.

Op den spitsen heuvel Wedon, anderhalve paal Noord, links,

1 Vgl. Rapp. 1902 p. 337. 
West van den weg, en onder 't gebied van het district Porrong, is een groot vierkant gebouw of altaar geweest, van gehouwen trachiet, een offerstede, petapahan of kluizenarij, met een opstaanden steen als grafzerk, beschreven met onduidelijke karacters ${ }^{1}$.

De wedono van Redjassa-Passaroewan, verhaalde in Augustus 1868: dat hij veertien jaren achtereen was geweest wedono van het district Porrong-Passaroewan (1852-1865); dat hij alle de trachietsteenen van den Wedon heeft laten afhalen, ongeveer 200 , om een brug in den grooten weg naar Passaroewan (Toempang) te verbeteren, bruggehoofden te maken; dat, daar hij van den Wedon steenen te weinig kreeg, hij vervolgens een oude bedolven badplaats heeft laten opbreken in de dessa Pager (Porrong, Pandahan) en van daar 1400 trachietsteenen kreeg.

En zóó werden Wedon en Pager herschapen tot een modern doel ; oud-nieuwheden.

\section{SOEMBER POELOET.}

Op het vroegere huurland Genitri, Noordoost van Malang hoofdplaats, vond de huurbezitter in 1858 een gemetselden, maar nu gevulden vijver van trachietsteen, even als die van Windit voor eene badplaats geschikt en bestemd geweest, toen onder struiken in wildernis bedolven en gedempt.

(Opgave van C. L. Mentel, den vinder).

\section{BATOE-SISIR.}

(Verbeek no 604; Rapp. 1902 p. 322).

Nabij den Passangrahan, onder boomen een verzameling van elders aangevoerd. Alle van de leersekte van Siva.

Twee Mahadewa's, waarvan een van ongeveer vier voeten hoog, vóórdeel van 't hoofd afgeslagen; de kin, baard en hals overig. Een enkele band van den hals afhangende. In de linkerhand eene waterkruik. In de regterhand een kleine bidsnoer. De eene het hoofd afgeslagen; houdt in de hand een trisoela, drietand, Siva's staf.

Twee Nandi's.

1 Over Wĕdon vgl. Tijdschr. Aardr, Gen. 32 (1915) p. 215. 
Twee Doerga's, zonder hoofd, 8 armen.

Eene Ganesa.

Een beeldje zittend, met een bloem in elke hand.

Twee kleine Gorgona, Kalahoofden.

Eene Lingga, nu voor een watergoot in een bak gebezigd, zonder zichtbare profanatie.

\section{EILAND MADOERA.}

$\mathrm{Er}$ is weinig historische zekerheid over den vroegeren toestand op het eiland Madoera. Het volgde grootendeels den loop der zaken op het tegenoverliggend Java.

De losse voorwerpen schijnen van Java herkomstig te zijn. De vaste, gebouwde, zijn van rooden baksteen; een paar fundamentwerken van trachiet, of marmer uit het land zelve.

Ik vond beelden te Bankalan, Blega, Tjandi, Soemenap, oude badplaatsen te Soemenap, Pamekasan, oude gebouwen te Arosbaya, Palakaran, Peroppo, losse voorwerpen te Sampang, Soemenap. Maar het land is nog niet genoegzaam doorzocht.

Oude Hindoebeelden.

Q. M. R. Verhuell duidt aan, op 1819 , dat hij naar Bankalan reed, en aan den ingang van de hoofdplaats twee ruwe beelden zag staan, soort van knodsdragers, wachters، Die beelden stonden er in latere jaren nog, en schijnen eerst in 1861 naar elders vervoerd te zijn, vermoedelijk naar Batavia (Notulen Bat. Gen. IV, 1; I, 16; Tijdschr. B. G. X, 16).

De herkomst was onbekend. Bankalan werd aangelegd in 1742-46. Bevorens was Toerdjoeng de zetelplaats. Dáár is alles geraseerd en verdweenen.

De meest nabij gelegene oude vestiging is Arosbaya, waar in de wildernis nu nog de overblijfselen liggen van een baksteenen gebouw van blijkbaar laten tijd, na 't Hindoe-tijdvak. Vermoedelijk is dit het gebouw van den landsheer, bedoeld in de togten van Houtman, 1595, en Van Neck, 1598. In de reis van de Brito, 1511, is er nog van Arosbaya geene spraak.

Verhuell beschreef de bedoelde beelden:

"een triumfboog aan het einde van den weg, bij de hoofdplaats. Aan elke zijde vervaarlijk groote reuzenbeelden, met 
monsterachtige aangezichten en zwaarden, onder afdakjes gesteld, met levendige kleuren beschilderd, aan den ingang van den alonalon.

Zulke beelden vind men op Java veel bij Braminsche tempels.»

Beelden te Blega.

In de woningen der te Blega aan de rivier wonende Chinezen, vond ik twee ruwe Hindoebeelden, wier herkomst onbekend, doch vermoedelijk van den Zuidelijken overwal, land van Probolinggo-Passaroewan te nemen was.

Bij den Chinees Tio ho kan een ruwe voorstelling van Doerga, een paar voeten hoog, als voorwerp van offering gebezigd, in een afzonderlijk deel van het huis opgesteld op den grond, op een pedestal. Bij den Chinees Lo Goan hong, een zittend beeld, Boeddhavorm, ruw of beschadigd, verweerd. De Boeddha was nog geen twee voeten hoog.

Beide beelden van trachietsteen, doch veel hebbende van gevormd, gedroogd te zijn, maar antiek, overeenkomende met de Javasche (1862).

In den Passangrahan te Blega vond ik een bewerkt stuk trachiet, dat vermoedelijk een trapleuning-stuk geweest was.

Later gaf men mij op, dat die beelden waren gevonden in den grond, op het veld, bij omspitting om de Zuidoost van de dessa Blega, dus inheemsch, niet van elders aangebragt.

Beeldwerk in Soemenap.

Volgens mededeelingen in de notulen der Directie Bat. Gen. vergaderingen in het Tijdschr. B. G. werden er gevonden :

Deel IX (1858), 297, 298 een beeld.

Deel X (1859), 298 een beeld met karacters als inscriptie, waarvan eene teekening werd aangeboden.

Welke voorstellingen dit waren is mij niet gebleken, en ook niet nader aangeduid. Ik deed er in 1862 te vergeefs navraag naar.

Volgens deel IX T. B. G., 244 werd er ook een metalen klok gevonden en naar Batavia verzonden. Doch daar oordeelde men dat dit Boeddhistisch instrument geene oudheidkundige waarde had. De herkomst is niet opgegeven.

In de zout-dessa Tjandi-papak, op de grens van de regentschappen Pamekasan en Soemenap, is voor de aanduiding van dien naam, niets anders vertoonbaar, als het hoofd van een 
beeld van trachiet, vermoedelijk Boeddhaisch. Van een Tjandi (graf-kapel) is niets bekend bij de tegenwoordige bewoners. De Chinezen offeren aan dit fragment. Ik nam het vroeger voor eene Doerga.

Men deelde mij in 1862 te Soemenap mede, dat er vroeger in de Chineesche, en in de zeemanswijken een paar beelden stonden van Doerga en Siva; dat de Chinezen die beelden, als landspalladium, hadden begraven, verborgen, verstopt, om vervoer of ontheiliging voortekomen, daar de Mohammedaansche landshoofdlieden zulke voorwerpen vernielden ${ }^{1}$.

\section{Peroppo ${ }^{2}$.}

West van Pamekassan, en van het suikeretablissement Teedja; in een heuvelige, golvende streek, nu weinig bewaterd, maar nabij de diepe kloofbronnen Soemberpayong, die zeven palen Westwaarts van Teedja liggen. Ongeveer negentig voeten boven zee, en zes palen benoorden de Zuidkust van 't land Tjettjerrěh.

Overblijfsel van een grooter gebouw van rooden baksteen, op een nederig heuvelplekje, te midden van omploegd veld (1862). Tot op vijftig roeden in den omtrek is de grond bedekt met roodbaksteenen afbraak, voor galangan (velddammen) als andersinds. Twee groote, sterk begroeide hoopen steen, aan de Noordzijde van de hoofdruïne, schenen wachthuisjes geweest te zijn.

De breedte van het overgebleven muurwerk is, langs den grond, ongeveer nog achttien voeten. De hoogte, op één punt, evenzoo, achttien. Alles is met geweld en breekijzermagt vernield. De diepte zal achttien voet geweest zijn.

Hier stond dus een Tjandi, een torengebouw ? De afpalingen, vierhoekige vakken aan de Noordzij, en de twee begroeide steenhoopen, schijnen het overschot van een grooter gebouw geweest te zijn.

Aan de Noordzijde liet een deel der ongebroken muur twee vierkante vakken, lijst en krulwerk zien; ook vermoedelijke figuren van menschen en dieren. Een dikke geelbladerige boom scheen hier als wachter ongedeerd te zijn gebleven. Wandalisme had al het andere aangerand. Die handdadigen zijn bekend. Het waren de zoekers naar schatten, die evenwel groote nadeelen

I Vgl. Rapp. 1908 p. 12.

3 Vgl. Rapp. 1908 p. 8, waar van twee vervallen tjandi's wordt melding gemaakt. 
vonden. De Madoerees heeft met koevoet, breekijzer en moker de muren doorbroken, om naar verborgen schatten te zoeken. Zóó verhaalt men.

De muren zijn afgebroken om de steenen te bezigen voor den opbouw der Suikerfabriek Teedja. Die baldadigheid geschiedde in 1840, op last van den landsregent, zoogenaamden Panembahan, ten behoeve van den oprigter Dr. Mulder. De goden hebben zich gewroken! Elk eigenaar van die suikeronderneming sinds 1840 heeft groote verliezen, nadeelen ondervonden; een paar werden arm. Dit gebeurde zevenmalen, tot 1866.

Peroppo was vermoedelijk een kadaton, evenals Koetorono, Koetoboro; het dagteekent van den tijd van het laatste Hindoegebied van Modjopait.

De overlevering duidde aan, dat de omwroeters der steenmassa's nu en dan goudwerken hadden gevonden.

Van den Zuidkant der ruïne peilde ik Argopoero, spits, hoogste punt Yanggeb. Z. $\frac{3}{4} \mathrm{O}$.

De steenen waren van de Modjopaitsche struktuur, helder rood, vast, doch kleiner van vorm als bij de Modjopait-oudheden, vingeveer dis te inatjanpoet, Koetorono, ivgardipoero; zonder cement, door geene wringin of lianen ontworteld, maar met menschenwoede verbroken. Het loofwerk geleek veel op dat van de Tjandipari, Delta Soerabaya; niet zeer fijn. Het reliefwerk in het vleesch van den steen uitgehouwen. De twee overgebleven reliefvakken op den Zuidkant geleken ongeveer op die van Boroboedoor en Djago, wat den vorm aangaat, door lijst- en loofwerk omgeven; de gedaanten onkenbaar geworden.

Inwendig een enkele begroeide puinhoop. Bovendeel onkenbaar, niet te bepalen. De Oostzijde deels nog staand, aangebroken muurwerk; West en Noord zijn totaal vernield. Het muurwerk scheen lomp-kolossaal, het reliefwerk ruw geweest te zijn, even als te Dermo.

De gelegenheid, het oord, was vermoedelijk vroeger wélgekozen, maar thans waterarm, de omgeving deels bouwland geworden; alle antiquarische waarde en alle woestheid was verdwenen.

Van vroegere tijden kwam mij over dezen bouwval enkel een aanduiding voor van Domis, 1830, in de Oosterling, - bij Olivier, - en in het woordenboek van Van der Aa, alles uit ééne bron, uit berigten van $1830,1834,1845$. Dat de berigten 
aanvankelijk niet van eigen onderzoek in loko kwamen, bewijst de eenige opgave in het woordenboek van 1845 op: S, Soemenap, afkomstig van H. J. Domis, 1830:

"In de streek van Soemenap (de afdeeling, waaronder vroeger ook Pamekasan behoorde) en wel te Pajong, wordt eene tempelruïne gevonden, met beelden van Siwa en Boeddha».

Daar de bronwellen van de rivier van Pamekasan, genoemd worden Soember-payong, en deze nabij de ruïne van Propo= Peroppo liggen, zoodat met het bezoek van de eene ook dat der andere volgt, zoo zal met die tempelruïne bedoeld zijn : Peroppo, bij Payong. In Soemenap is Tjandi Pajong ook onbekend.

Van die beelden vond ik niets. Welligt zijn de beelden te Blega en Tjandipapak van hier afkomstig. Te Soemenap moeten een paar beelden door Chinezen begraven zijn ter betere bewaring.

Palâkaran.

Nabij en Noord van den grooten weg, tusschen paal $\mathrm{N}^{\circ}$. 45-46, zes palen Noordwest van de hoofdplaats Sampang, voorbij de post Tordjong; in onbewoonde wildernis.

Muren en fragmenten van rooden baksteen, -- zonder beelden of beeldwerk.

Voormalig verbijf van een landsopperhoofdman, in den Mohammedaanschen tijd waarschijnlijk, evenals de ruïnen bij Arosbaya.

Welligt het oude Maduretna der kaart van Relandus, 1690, of wel het speciaal aangeduide "Madure». 
INHOUD.

Blz.

Matjan poeti. . . . . . . . . . . . . . 415

Tjandi Bang. . . . . . . . . . . . . . . 417

Poerwanegara . . . . . . . . . . . . . 418

Keradennan . . . . . . . . . . . . . . . 418

Djangkar . . . . . . . . . . . . . . . . . 419

Land van Poeger . . . . . . . . . . . . . . . 419

Smeroe . . . . . . . . . . . . . . . . . . 421

Tjandi Ngardipoero . . . . . . . . . . . . . 422

Koeto-rono . . . . . . . . . . . . . . . . 424

Probolinggo . . . . . . . . . . . . . . . . . 425

Land van Padjarakkan . . . . . . . . . . . . 426

Moender . . . . . . . . . . . . . . . . 427

Koeto-boro . . . . . . . . . . . . . . . . 427

Kroekoep . . . . . . . . . . . . . . . 428

Kroetjil . . . . . . . . . . . . . . . . . 428

Batoe-lantjang . . . . . . . . . . . . . . 429

Telogo-Indro. . . . . . . . . . . . . . . . . 430

Telogo-sari . . . . . . . . . . . . . . . . 431

Passaroewan. . . . . . . . . . . . . . . 431

Tjabang Bauën. . . . . . . . . . . . . . 434

Tjandi Rah-tawoe . . . . . . . . . . . . . . 434

Badplaats Pager . . . . . . . . . . . . . 434

Dermo. . . . . . . . . . . . . . . . . 435

Indrokilo . . . . . . . . . . . . . . . . . . . . 437

Badplaats Banjoebiroe . . . . . . . . . . . 438

Tjandi Pari . . . . . . . . . . . . . . 440

Soerabaya . . . . . . . . . . . . . . . . 442

Singosari . . . . . . . . . . . . . . . 444

Malang . . . . . . . . . . . . . . . . 447

Djago-Toempang . . . . . . . . . . . . . 447

Tjoemkop Kidal . . . . . . . . . . . . . . 449

Singoriti . . . . . . . . . . . . . 450 
INHOUD.

Blz.

Loemadjang-tenga . . . . . . . : . . . . . . 450

Ngendat . . . . . . . . . . . . . . . . 451

Bedji . . . . . . . . . . . . . . . . . 451

Wedon. . . . . . . . . . . . . . . . 451

Soember poeloet . . . . . . . . . . . . . . . 452

Batoe-Sisir . . . . . . . . . . . . . . . . . 452

Eiland Madoera . . . . . . . . . . . . . 453

Beelden . . . . . . . . . . . . . . . 453

Peroppo . . . . . . . . . . . . . . . 455

Palâkaran . . . . . . . . . . . . . . . 457 